\title{
Naphthoquinones of natural origin: Aqueous chemistry and coordination to half-sandwich organometallic cations
}

\author{
János P. Mészáros a,b,1, Heiko Geisler ${ }^{c, 1}$, Jelena M. Poljarevića,d, Alexander Roller ${ }^{c}$, Maria S. Legina ${ }^{c}$, \\ Michaela Hejl ${ }^{c}$, Michael A. Jakupec ${ }^{\text {c,e }}$, Bernhard K. Keppler ${ }^{c, e}$, Wolfgang Kandioller ${ }^{c, e}$, Éva A. Enyedy ${ }^{\text {a,b,* }}$ \\ a Department of Inorganic and Analytical Chemistry, Interdisciplinary Excellence Centre, University of Szeged, Dóm tér 7, H-6720, Szeged, Hungary \\ b MTA-SZTE Momentum Functional Metal Complexes Research Group, University of Szeged, Dóm tér 7, H-6720, Szeged, Hungary \\ c Institute of Inorganic Chemistry, Faculty of Chemistry, University of Vienna, Währinger Str. 42, A-1090, Vienna, Austria \\ d Faculty of Chemistry, University of Belgrade, Studentski trg. 12-16, 11000, Belgrade, Serbia \\ e Research Cluster "Translational Cancer Therapy Research”, University of Vienna, Währinger Str. 42, A-1090, Vienna, Austria
}

\section{A R T I C L E I N F O}

Article history:

Received 28 October 2019

Received in revised form 5 December 2019

Accepted 6 December 2019

Available online $\mathrm{xxx}$

Keywords

Solution stability

X-ray crystal structures

Cytotoxicity

Natural ligands

Half-sandwich complexes

\begin{abstract}
A B S T R A C T
Half-sandwich organometallic complexes featuring Ru(II), Os(II) and Rh(III) metal centers and naturally occurring bidentate 2-hydroxy-[1,4]-naphthoquinone ligands (lawsone and phthiocol) have been synthesized and characterized in both solid state and solution phase by analytical, spectroscopic, electrochemical and single crystal $\mathrm{X}$-ray diffraction techniques. Comparative studies revealed the influence of the respective metal center $(\mathrm{Ru}, \mathrm{Os}$, $\mathrm{Rh}$ ), leaving group $(\mathrm{Cl}, \mathrm{Br}, \mathrm{I})$ and arene ( $p$-cymene, toluene, pentamethylcyclopentadienyl), as well as the naphthoquinone ligand on the structural properties and solution speciation. Additionally, cytotoxicity was tested in SW480, CH1/PA-1 and A549 human cancer cell lines showing a broad range of $\mathrm{IC}_{50}$ values.
\end{abstract}

(C) 2019

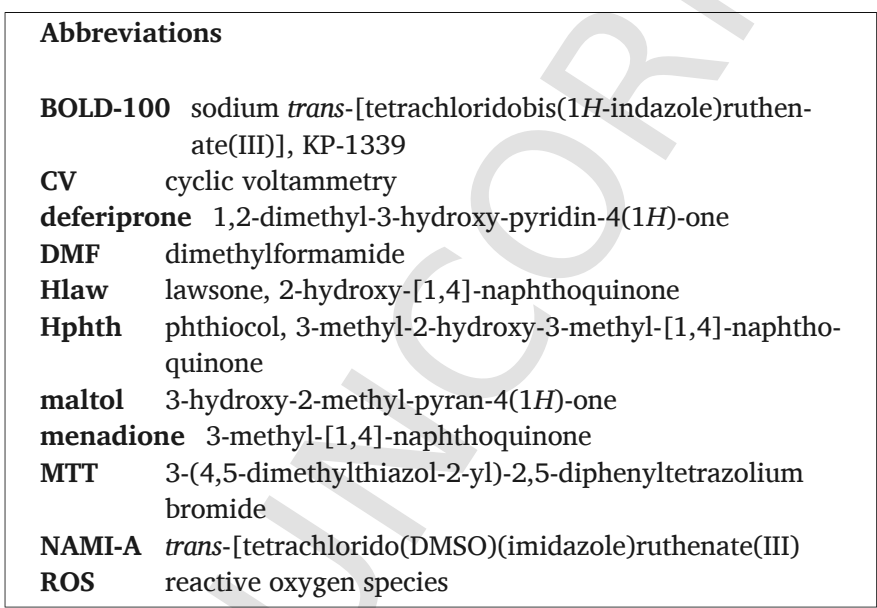

\footnotetext{
* Corresponding author. Department of Inorganic and Analytical Chemistry, Interdisciplinary Excellence Centre, University of Szeged, Dóm tér 7, H-6720, Szeged, Hungary.

E-mail address: enyedy@chem.u-szeged.hu (É.A. Enyedy)

1 Both authors contributed equally to this work.
}

\section{TGA thermogravimetric analysis}

\section{Introduction}

Due to the reoccurring limitations with well-established Pt(II) drugs (e.g. cisplatin) in cancer treatment, much research effort has been focused on the search for other metallodrugs with different activity profiles and lower toxicity $[1,2]$. In this context, metal center variation brought to light the possible suitability of Ru based drugs. At this time $\mathrm{Ru}(\mathrm{III})$ compounds, as well as $\mathrm{Ru}(\mathrm{II})$ "piano-stool" complexes are extensively investigated. Two well-known examples of Ru(III) drug candidates are BOLD-100 (sodium trans-[tetrachloridobis( $1 \mathrm{H}$-indazole)ruthenate(III)], formerly KP-1339 or IT-139), which is about to enter clinical phase II studies, and NAMI-A (trans-[tetrachlorido(DMSO)(imidazole)ruthenate(III)]). Both of these complexes highlight the importance of the metal's coordination sphere (Fig. 1). While BOLD-100 features two indazole ligands and is active against primary tumors as well as metastases, its structurally related congener NAMI-A only shows activity against metastases [3,4].

On the other hand, organometallic Ru(II) complexes often feature a stabilizing arene moiety, and mono-, or bidentate ligands, as well as a leaving group. The name of these so-called "piano-stool" complexes is 

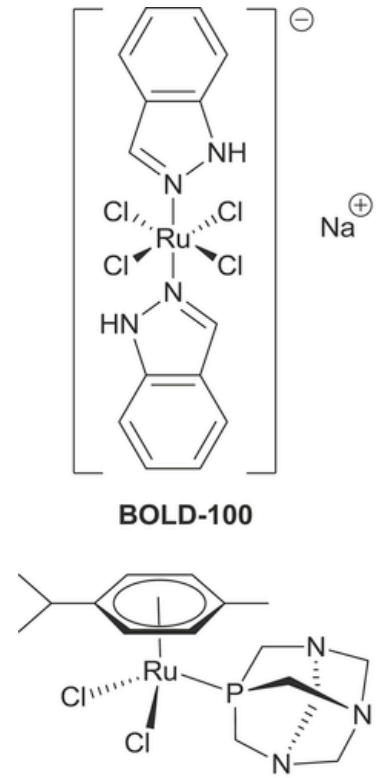

RAPTA-C

Fig. 1. Structural formulae of Ru(III) and Ru(II) drug candidates, which are currently undergoing or have undergone (pre)-clinical trials.

derived from the resulting geometrical form, which resembles a three legged stool, where the arene is the seat and the other ligands are the legs. The most advanced and extensively studied drug candidates, RM175 and RAPTA-C (Fig. 1) are believed to have completely different modes of action. While Sadler et al. postulated that RM175 interacts with DNA via intercalation of the biphenyl moiety and covalent binding to nucleobases; activity of RAPTA-C is ascribed to protein interaction [5]. However, no "piano-stool" complex has been evaluated in clinical studies so far.

Another approach is the synthesis of Ru(II) "piano-stool" complexes featuring bioactive natural products with anticancer properties. Many natural compounds such as quinones and naphthoquinones are found in plants, algae, and bacteria and used as versatile building blocks for organic synthesis of medicinal drugs [6,7]. Other members of this family are phthiocol and lawsone, which are considered as derivatives of vitamin K (Fig. 2) $[6,8,9]$.

Naphthoquinones readily act as reducing agents leading to the formation of radicals and reactive oxygen species (ROS) [10]. In the past, several quinones and naphthoquinones were biologically tested and revealed cytostatic properties $[6,7,11-13]$. Half-sandwich organometallic complexes containing 2-hydroxy-[1,4]-naphthoquinones as ligand scaffold have already been reported in literature with promising results [14-16]. Furthermore, heterobimetallic compounds with a pendant ferrocene moiety have been investigated for their anticancer properties $[17,18]$. Physicochemical properties (e.g. solubility, lipophilicity), biologic parameters (e.g. $\mathrm{IC}_{50}$ values, mode of action) as well as solution equilibrium constants are crucial factors in drug development. One of the main advantages of using "piano-stool" complexes is the possibility to fine-tune these physicochemical properties, namely stability, redox properties, solubility via ligand modification and variation of the metal center or the leaving group $[19,20]$.<smiles>CC1=CC(=O)c2ccccc2C1=O</smiles><smiles>COc1ccccc1C(=O)O</smiles><smiles>O=C1C=C(O)C(=O)c2ccccc21</smiles>

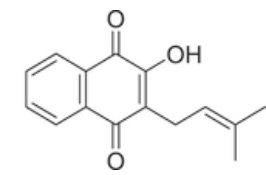

Fig. 2. Structural formulae of vitamin K3 (menadione) and its naphthoquinone derivatives: phthiocol, lawsone, and lapachol (from left to right).
Herein we report the synthesis, characterization, detailed solution stability and complex formation properties of six new "piano-stool" complexes. These organometallics feature either 3-methyl-2-hydroxy-3-methyl- [1,4]-naphthoquinone (phthiocol, Hphth) or its non-methylated analogue 2-hydroxy- [1,4]-naphthoquinone (lawsone, Hlaw) as O,O-chelates for Ru(II)-, Os(II)- and Rh(III)-arene organometallic ions. Additionally, cytotoxicity tests in human cancer cell lines were conducted in order to assess the anticancer potency of these compounds.

\section{Results and discussion}

\subsection{Synthesis}

Lawsone is commercially available, phthiocol was synthesized in a two-step synthesis, starting from commercially available 3-methyl$[1,4]$-naphthoquinone (menadione), according to literature with minor modifications $[21,22]$. Firstly, an epoxide intermediate was formed, using aqueous hydrogen peroxide solution (30\%). Ring opening reaction was performed with concentrated sulfuric acid and silica gel in THF and provided good yields $(72 \%)$ over two steps (Scheme S1).

The phthiocol-based Ru(II)-p-cymene complex (KP2048) showed promising anticancer activity in vitro and in vivo experiments [14]. Within this work, we wanted to investigate the effect of different metal centers (Ru(II), Os(II), Rh(III)), halide leaving groups $\left(\mathrm{Cl}^{-}, \mathrm{Br}^{-}, \mathrm{I}^{-}\right)$, arenes ( $p$-cymene, toluene, $\mathrm{C}_{5} \mathrm{Me}_{5}{ }^{-}$) and ligands on the solution behavior and cytotoxic potency.

The desired complexes (1-7) were obtained by the deprotonation of the 2-hydroxy-naphthoquinone (phthiocol or lawsone) with sodium methoxide in dry methanol, followed by the addition of the respective dimeric metal precursor $\left(\left[\mathrm{MX}_{2}(\text { arene })\right]_{2}\right)$ (see Scheme 1). Following the standard purification reported in literature [16], the complexes were isolated in moderate-to-good yields. Two different methods were applied to obtain the desired complexes. In method A: the starting materials were reacted under standard conditions $\left(20-40{ }^{\circ} \mathrm{C}\right)$ for 2-24 h. The other method (method B) included microwave irradiation for $6-14 \mathrm{~min}$ at $40-50{ }^{\circ} \mathrm{C}$. Both methods were used for all complexes. However, the microwave assisted method reduced the reaction time of complexes 2, $\mathbf{4}$ and $\mathbf{5}$ considerably. After purification, yields between 15 and $90 \%$ were obtained.

\subsection{Crystal structures of phthiocol complexes}

Single crystals of five complexes $(\mathbf{1}-\mathbf{3}, 5-6)$ were obtained by liquid-liquid diffusion from dichloromethane $/ n$-hexane (see Figs. 3 and 4). These complexes exhibit a pseudo-octahedral geometry with a ligand-to-metal ratio of 1:1. The arene, the bidentate naphthoquinone ligand (Hphth) and the monodentate halide ion are coordinated to the metal center and adopt the characteristic "piano-stool" configuration.<smiles>[X][M]OC1=C([R])C(=O)c2ccccc2C1=O</smiles>

(1) $=\mathrm{M}=\mathrm{Ru} ; \mathrm{R}=\mathrm{CH}_{3} ; \mathrm{X}=\mathrm{Cl} ;$ Arene $=p$-cymene $(56 \%)$

(2) $=\mathrm{M}=\mathrm{Ru} ; \mathrm{R}=\mathrm{CH}_{3} ; \mathrm{X}=\mathrm{Br} ;$ Arene $=p$-cymene $(66 \%)$

(3) $=\mathrm{M}=\mathrm{Ru} ; \mathrm{R}=\mathrm{CH}_{3} ; \mathrm{X}=\mathrm{I} ;$ Arene $=p$-cymene $(71 \%)$

(4) $=\mathrm{M}=\mathrm{Ru} ; \mathrm{R}=\mathrm{CH}_{3} ; \mathrm{X}=\mathrm{Cl} ;$ Arene $=$ toluene $\quad(90 \%)$

(5) $=\mathrm{M}=\mathrm{Os} ; \mathrm{R}=\mathrm{CH}_{3} ; \mathrm{X}=\mathrm{Cl} ;$ Arene $=p$-cymene $(18 \%)$

(6) $=\mathrm{M}=\mathrm{Rh} ; \mathrm{R}=\mathrm{CH}_{3} ; \mathrm{X}=\mathrm{Cl} ;$ Arene $=\mathrm{C}_{5} \mathrm{Me}_{5} \quad(75 \%)$

(7) $=\mathrm{M}=\mathrm{Ru} ; \mathrm{R}=\mathrm{H} ; \quad \mathrm{X}=\mathrm{Cl} ;$ Arene $=p$-cymene $(69 \%)$

Scheme 1. Synthetic pathway for complex synthesis. 


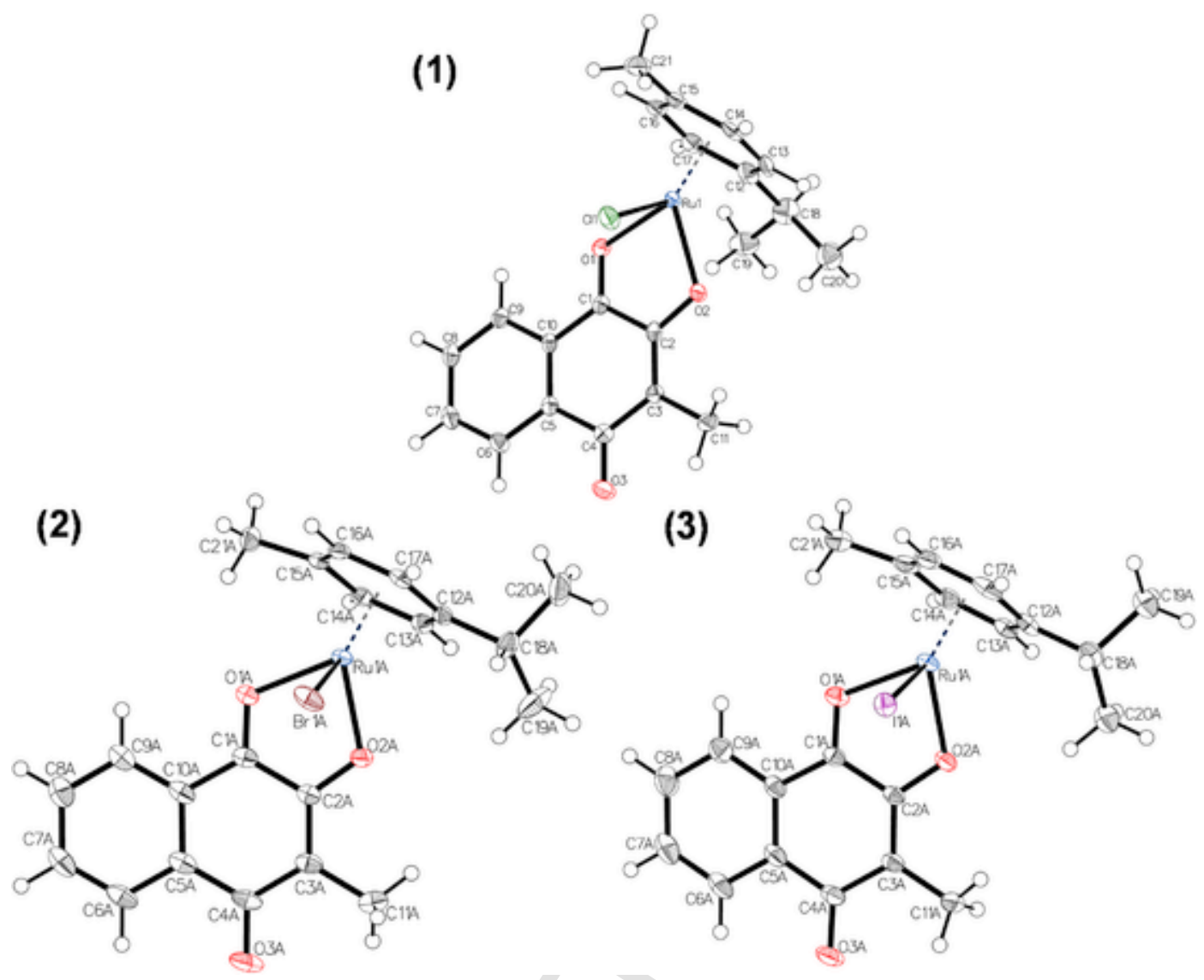

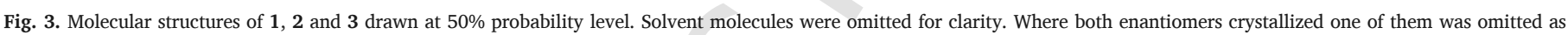
well.
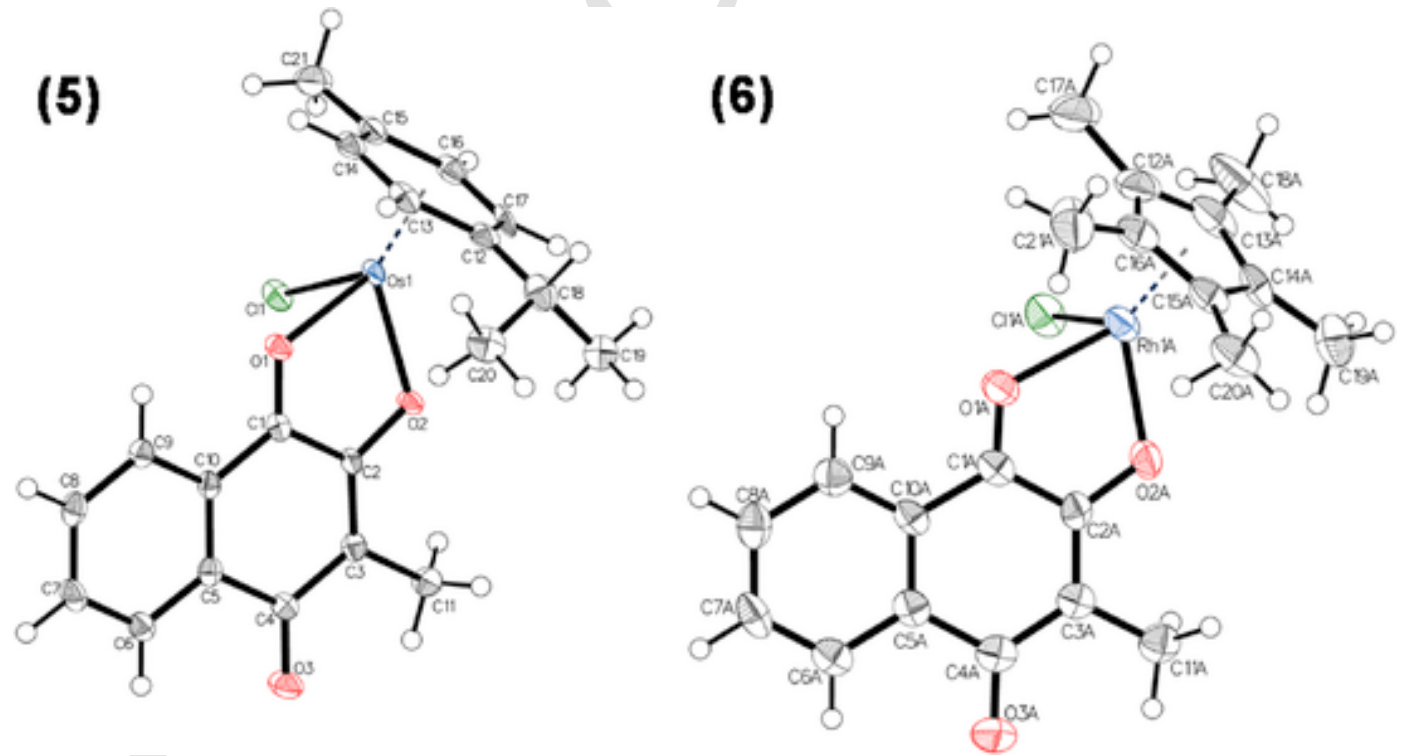

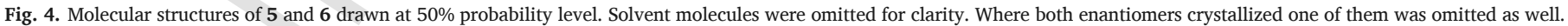

Complexes 2,3 , and $\mathbf{6}$ crystallized in the triclinic space group P $\overline{1}$. Compounds 1 and 5 crystallized in the monoclinic space group P2 $1 /$ c.

The bond lengths between the donor atoms of phthiocol and the metal center and bond angles are shown in Table 1 . The variation of the metal center $\mathrm{Ru}(\mathrm{II})$ (1) to Os(II) (5) has no relevant impact on the bond lengths and angles. However, the Rh(III) complex 6 exhibits a slight elongation of the coordination bonds, compared to the $\mathrm{Ru}(\mathrm{II})$ ana$\log 1$.

Based on these data the variation of halide ions has no relevant effect on geometric parameters in the coordination sphere. These organometallic complexes possess a chiral metal center and both enantiomers were found in the unit cell of complexes 2,3 and 6 . 
Table 1

Selected bond lengths, bond angles and torsion angles for the phthiocol complexes: $(1-3$, 5-6).

\begin{tabular}{|c|c|c|c|c|c|}
\hline & 1 & $2^{\mathrm{a}}$ & $3^{a}$ & 5 & $6^{a}$ \\
\hline \multicolumn{6}{|c|}{ Bond distances $[\AA]$} \\
\hline $\mathrm{M}-\mathrm{C}_{\mathrm{g}}$ & 1.651 & 1.646 & 1.651 & 1.651 & 1.743 \\
\hline M-O1 & $2.119(2)$ & $2.123(2)$ & $2.122(3)$ & $2.119(3)$ & $2.160(4)$ \\
\hline M-O2 & $2.092(2)$ & $2.082(2)$ & $2.085(3)$ & $2.092(4)$ & $2.095(5)$ \\
\hline $\mathrm{M}-\mathrm{X}$ & $2.403(1)$ & $2.532(4)$ & $2.711(4)$ & $2.394(1)$ & $2.390(2)$ \\
\hline \multicolumn{6}{|c|}{ Bond angles $\left[{ }^{\circ}\right]$} \\
\hline O1-M-O2 & $76.31(8)$ & $76.39(8)$ & $76.18(9)$ & $75.60(1)$ & $76.25(2)$ \\
\hline $\mathrm{O}-\mathrm{M}-\mathrm{X}^{\mathrm{b}}$ & $84.89(7)$ & $85.61(5)$ & $86.17(8)$ & $83.66(8)$ & $87.63(4)$ \\
\hline
\end{tabular}

a Calculated average of the two isomers in one unit cell.

${ }^{\mathrm{b}}$ Calculated average value of O1-M-X and O2-M-X.

\subsection{In vitro anticancer activity of compounds}

The cytotoxicity of 2-hydroxy- [1,4]-naphthoquinones depends on the nature of alkyl substituents at position 3 [13]. Cytotoxic activities of Hphth, Hlaw and the respective complexes 1, 4-7 were determined in human colon carcinoma (SW480), ovarian teratocarcinoma (CH1/PA-1) and non-small cell lung carcinoma (A549) cells by means of the colorimetric 3-(4,5-dimethylthiazol-2-yl)-2,5-diphenyltetrazolium bromide (MTT) assay (Table 2). No $\mathrm{IC}_{50}$ values could be determined for complexes $\mathbf{2}$ and 3, due to the poor solubility in aqueous systems.

All tested complexes 1, 4-7 showed at least a tendency for increased cytotoxicity in the intrinsically chemo-resistant (P-glycoprotein-expressing) human cancer cell line SW480, compared to the free ligands (Hphth, Hlaw). The combination of Ru(II) and $p$-cymene yields a clearer increase of cytotoxicity in all cancer cell lines employed, whereas the other variants with a different metal center (6) or arene ligand (4) showed only marginally increased cytotoxicity in the cell line SW480 and no enhanced activity in A549 and CH1/PA-1 cells.

Based on these data we could conclude that the tested compounds exhibited a broad range of anticancer potency with $\mathrm{IC}_{50}$ in the range of $15 \mu \mathrm{M}$ to $>200 \mu \mathrm{M}$. Generally the dimeric organometallic precursors do not exhibit strong cytotoxicity ( $>100 \mu \mathrm{M}\left[\mathrm{RuCl}_{2}\left(\eta^{6}-p \text {-cymene) }\right]_{2}\right.$ reported for several cancer cell lines $[25,26]$, and both naphthoquinone ligands showed $\mathrm{IC}_{50}$ values $>100 \mu \mathrm{M}$. The arene change resulted in a loss of activity compared to the $p$-cymene derivative $\mathbf{1}$, as did the metal center variation from $\mathrm{Ru}(\mathrm{II})$ to $\mathrm{Os}(\mathrm{II})$ or $\mathrm{Rh}(\mathrm{III})$. Introduction of the lawsone ligand was not beneficial with regard to cytotoxicity either, but complex 7 was still more active than the free ligand Hlaw.

Table 2

Cytotoxicity of ligands, their corresponding half-sandwich organometallic complexes (1, 4-7) and cisplatin and RAPTA-C for comparison in three different human cancer cell lines using $96 \mathrm{~h}$ incubation time.

\begin{tabular}{llll}
\hline $\mathrm{IC}_{50}[\mu \mathrm{M}]$ & A549 & SW480 & CH1/PA-1 \\
\hline $1^{\mathrm{a}}$ & $47 \pm 4$ & $15 \pm 3$ & $31 \pm 10$ \\
$\mathbf{4}$ & $\mathrm{IC}_{50}>100$ & $87 \pm 6$ & $\mathrm{IC}_{50}>100$ \\
$\mathbf{5}$ & $111 \pm 23$ & $81 \pm 18$ & $59 \pm 12$ \\
$\mathbf{6}$ & $\mathrm{IC} \mathrm{C}_{50}>200$ & $96 \pm 17$ & $\mathrm{IC}_{50} \sim 200$ \\
Hphth & $210 \pm 32$ & $116 \pm 37$ & $129 \pm 29$ \\
7 & $98 \pm 24$ & $86 \pm 20$ & $84 \pm 15$ \\
Hlaw $_{\text {cisplatin }}{ }^{\mathrm{b}}$ & $157 \pm 13$ & $247 \pm 17$ & $246 \pm 24$ \\
RAPTA-C $^{\mathrm{c}}$ & $6.2 \pm 1.2$ & $3.3 \pm 0.2$ & $0.077 \pm 0.006$ \\
\hline
\end{tabular}

a Data are taken from Ref. [14].

b Data are taken from Ref. [23].

c Data are taken from Ref. [24].

\subsection{Solution chemistry}

Investigation of solution behavior and determination of stability constants of bioactive metal complexes are key steps in drug development processes since from speciation data the biologically active chemical forms can be predicted. Thus this kind of information can help in deepening the understanding of pharmacokinetic properties and the mechanism of action. Currently no speciation data have been reported for half-sandwich organometallic complexes of 2-hydroxy-[1,4]-naphthoquinones so far. Only a few studies on the time-dependent stability in buffered solutions can be found in literature [15].

In this work we investigated systematically the aqueous solution chemistry of metal-ligand systems containing phthiocol and organometallic triaqua complex cation $\left(\left[\mathrm{Ru}\left(\eta^{6}-p \text {-cymene }\right)\left(\mathrm{H}_{2} \mathrm{O}\right)_{3}\right]^{2+}\right.$, $\left[\mathrm{Ru}\left(\eta^{6} \text {-toluene }\right)\left(\mathrm{H}_{2} \mathrm{O}\right)_{3}\right]^{2+}$ and $\left.\left[\mathrm{Rh}\left(\eta^{5}-\mathrm{C}_{5} \mathrm{Me}_{5}\right)\left(\mathrm{H}_{2} \mathrm{O}\right)_{3}\right]^{2+}\right)$ in the presence of $0.2 \mathrm{M}$ chloride ions. $\mathrm{pH}$-potentiometry is not suitable for determining stability constants for these naphthoquinone complexes due to their low water solubility and high concentration demand of the technique. Therefore UV-VISIBLE (UV-VIS) titrations were performed where lower concentrations can be employed. Though the osmium complex 5 was synthesized and its in vitro cytotoxicity was determined, the solution chemical properties were not characterized here since the more pronounced and slower hydrolytic behavior of $\left[\mathrm{Os}\left(\eta^{6}-p \text {-cymene }\right)\left(\mathrm{H}_{2} \mathrm{O}\right)_{3}\right]^{2+}$ compared with $\left[\mathrm{Ru}\left(\eta^{6}-p \text {-cymene }\right)\left(\mathrm{H}_{2} \mathrm{O}\right)_{3}\right]^{2+}$ or $\left[\mathrm{Rh}\left(\eta^{5}-\mathrm{C}_{5} \mathrm{Me}_{5}\right)\left(\mathrm{H}_{2} \mathrm{O}\right)_{3}\right]^{2+}$ would make the studies fairly difficult $[27,28]$. Lawsone was also involved the studies to reveal the impact of the methyl group on the ligand scaffold on the solution chemical properties.

\subsubsection{Proton dissociation processes of naphthoquinones and hydrolysis of} the organometallic cations

The $\mathbf{P} \boldsymbol{K}_{\mathrm{A}}$ value is a key parameter of bioactive compounds, as it has a large effect on the pharmacokinetic properties considering the actual protonation state (and charge), and it also affects the pH-dependence of the lipophilicity. with the help of these constants it is possible to calculate the distribution of different protonated species and the average charge at a given $\mathrm{pH}$. phthiocol and lawsone have one dissociable proton, as only the hydroxyl group can lose a proton with increasing $\mathrm{pH}$. although the structures are similar, the methyl group in the third position has a great impact on the neighboring hydroxyl group. proton dissociation constants of lawsone and phthiocol were determined by UV-Vis titrations ( $\mathrm{I}=0.2 \mathrm{M} \mathrm{KCl}$, Fig. s1) and deprotonation occurs at much lower $\mathrm{pH}$ values in the case of lawsone $\left(\mathrm{P} K_{A}(\mathrm{Hl})=3.90\right.$ and 5.08 for lawsone and phthiocol, respectively, see Table 3). These data

Table 3

Proton dissociation constants ( $\mathrm{p} K_{\mathrm{a}}(\mathrm{HL})$ ) of Hlaw and Hphth and stability constants $(\log K$ $[\mathrm{M}($ arene $) \mathrm{L}])$ of their complexes. $\left\{\mathrm{T}=25.0{ }^{\circ} \mathrm{C}, I=0.2 \mathrm{M}(\mathrm{KCl})\right\}$.

\begin{tabular}{|c|c|c|c|c|}
\hline & & $\begin{array}{l}\mathrm{Ru}\left(\eta^{6}-p-\right. \\
\text { cymene) }\end{array}$ & $\begin{array}{l}\mathrm{Ru}\left(\eta^{6}-\right. \\
\text { toluene) }\end{array}$ & $\begin{array}{l}\mathrm{Rh}\left(\eta^{5}-\right. \\
\left.\mathrm{C}_{5} \mathrm{Me}_{5}\right)\end{array}$ \\
\hline \multirow[t]{3}{*}{ Hlaw } & $\mathrm{p} K_{a}(\mathrm{HL})^{\mathrm{a}}$ & & $3.90 \pm 0.01$ & \\
\hline & $\begin{array}{l}\log K \\
{\left[\mathrm{M}\left(\text { arene)L] }{ }^{\mathrm{a}}\right.\right.}\end{array}$ & $3.45 \pm 0.01$ & $3.31 \pm 0.02$ & $<3.1$ \\
\hline & $\begin{array}{l}\% \text { of } \\
{[\mathrm{M}(\text { arene }) \mathrm{L}]^{\mathrm{b}}}\end{array}$ & $0.01 \%$ & $<0.01 \%$ & $6.6 \%$ \\
\hline \multirow[t]{3}{*}{ Hphth } & $\mathrm{p} K_{a}(\mathrm{HL})^{\mathrm{a}}$ & & $5.08 \pm 0.01$ & \\
\hline & $\begin{array}{l}\log K \\
{[\mathrm{M}(\text { arene }) \mathrm{L}]^{\text {a }}}\end{array}$ & $4.04 \pm 0.03$ & $3.78 \pm 0.04$ & $3.52 \pm 0.03$ \\
\hline & $\begin{array}{l}\% \text { of } \\
{[\mathrm{M}(\text { arene }) \mathrm{L}]^{\mathrm{b}}}\end{array}$ & $0.04 \%$ & $<0.01 \%$ & $14.5 \%$ \\
\hline
\end{tabular}

\footnotetext{
a From UV-Vis spectrophotometric titrations.

b Calculated at $c(\mathrm{M}($ arene $))=c(\mathrm{~L})=100 \mu \mathrm{M}, \mathrm{pH}=7.40$.
} 
are in good agreement with literature data, although different conditions were used ( $\mathrm{I}=0.5 \mathrm{M} \mathrm{KCl})[29,30]$.

$\begin{array}{ccc}\text { Hydrolysis } & \text { of } & \text { the } \\ \left.R u\left(\eta^{6}-p \text {-cymene }\right)\left(\mathrm{H}_{2} \mathrm{O}\right)_{3}\right]^{2+} & \text { and } & \left.\left.\left[\mathrm{Ru}\left(\eta^{5}-\mathrm{C}_{5} \mathrm{Me}_{5}\right)\left(\mathrm{H}_{2} \mathrm{O}\right)_{3}\right]^{2+} \text {-toluene }\right)\left(\mathrm{H}_{2} \mathrm{O}\right)_{3}\right]^{2+}\end{array}$ organometallic complex cations has been characterized in detail previously $[27,28]$. In these organometallic triaqua cations and (their studied complexes) the bond between the metal ion and the arene is stable under the used conditions ( $\mathrm{pH}=2.0-11.5)$. Increasing the $\mathrm{pH} \mu$-hydroxido bridged dinuclear species are formed with the formula $\left[(\mathrm{M}(\text { arene }))_{2}(\mathrm{OH})_{2}\right]^{2+}$ and $\left[(\mathrm{M}(\text { arene }))_{2}(\mathrm{OH})_{3}\right]^{+}[27,28]$. Although Bíró et al. examined extensively the species formed from $\left[\mathrm{Ru}\left(\eta^{6}-p \text {-cymene }\right)\left(\mathrm{H}_{2} \mathrm{O}\right)_{3}\right]^{2+}$ in chloride ion containing medium and determined the overall stability constants for five different species, all the titrations can be described sufficiently by only the overall stability constants determined for $\left[(\mathrm{M}(\text { arene }))_{2}(\mathrm{OH})_{2}\right]^{2+}$ and $\left[(\mathrm{M}(\text { arene }))_{2}(\mathrm{OH})_{3}\right]^{+}$ $(I=0.2 \mathrm{M} \quad \mathrm{KCl}) \quad$ [31]. These constants are $\log \beta$ $\left[(\mathrm{M}(\text { arene }))_{2}(\mathrm{OH})_{2}\right]=-6.50, \quad-7.12, \quad-11.12$ and $\log \beta$ $\left[(\mathrm{M}(\text { arene }))_{2}(\mathrm{OH})_{3}\right]=-10.56, \quad-11.88, \quad-19.01 \quad$ for $\mathrm{M}($ arene $)=\mathrm{Ru}\left(\eta^{6}\right.$-toluene $), \mathrm{Ru}\left(\eta^{6}-p\right.$-cymene $)$ and $\mathrm{Rh}\left(\eta^{5}-\mathrm{C}_{5} \mathrm{Me}_{5}\right)$, respectively, and these data were used in this work as well $[27,28]$.

\subsubsection{Complex formation equilibria of naphthoquinones with organometallic ions}

Based on the crystallographic structures and literature data of other half-sandwich $\mathrm{Ru}(\mathrm{II})$ and $\mathrm{Rh}$ (III) complexes with $(\mathrm{O}, \mathrm{O})$ donors, mono complex formation is the most probable process under the applied conditions. The complexes of half-sandwich $\mathrm{Rh}$ and $\mathrm{Ru}$ complexes with $(\mathrm{O}, \mathrm{O})$ donors usually reaches the equilibrium state rather fast $[28,32-34]$. Because of the extended delocalized electron system, the complexes of phthiocol and lawsone have absorbance in the UV-Vis region, so spectrophotometric titration is a suitable method for following the complex formation and spectra were recorded at 1:1 and 1:2 metal-to-ligand ratios.

In Fig. $5 \mathrm{a}$ the pH-dependent UV-Vis spectra of the $\left[\mathrm{Ru}\left(\eta^{6} \text {-toluene }\right)\left(\mathrm{H}_{2} \mathrm{O}\right)_{3}\right]^{2+}-$ lawsone $(1: 1)$ system are shown. The spectra above $590 \mathrm{~nm}$ (see Fig. 5a inserted diagram) give the most valuable

informa- tion: neither the metal ion nor the ligand has absorption in that region. Spectral changes here directly show the formation of the formed metal complex. In the system with 1:2 metal-to-ligand ratio the absorbance change is relatively high making the determination of the stability constants more precise (Table 3 ). In Fig. $5 \mathrm{~b}$ the concentration distribution curves calculated with the stability constants and the absorbance at $590 \mathrm{~nm}$ are shown. The maximum of the formed complex is $11.4 \%$ at $\mathrm{pH} 4.72$, which demonstrates low solution stability. With $\left[\mathrm{Ru}\left(\eta^{6}-p \text {-cymene) }\left(\mathrm{H}_{2} \mathrm{O}\right)_{3}\right]^{2+}\right.$ the spectral changes are similar (Fig. S2) and the formation of the [M(arene)L] complex is detectable also around $590-600 \mathrm{~nm}$. However, with $\mathrm{Rh}\left(\eta^{5}-\mathrm{C}_{5} \mathrm{Me}_{5}\right)$ no complex formation occurred under the used conditions. Titration of lawsone with the organometallic ion at $\mathrm{pH} 7.4$ shows no interaction between them, and the linearity of the curve in Fig. S3 proves the lack of complex formation in the system. Only an upper limit could be provided for the stability constant of this complex in Table 3 .

The pH-dependence of UV-Vis spectra of $\left[\mathrm{Ru}\left(\eta^{6}-p \text {-cymene }\right)\left(\mathrm{H}_{2} \mathrm{O}\right)_{3}\right]^{2+}$, phthiocol and their 1:1 metal-to-ligand ratio system is shown in Fig. 6a. The detection of complex formation in the case of phthiocol is more difficult: there is only a minor spectral change at $\sim 600 \mathrm{~nm}$ with a maximum of 0.02 absorbance (see Fig. 6 a inserted figure); in this region only the metal complex absorbs photons. Based on this absorbance change, the complex formation shows a maximum at $\mathrm{pH}$ 5.1. Calculations approved the low stability of the formed complex as the concentration distribution curves represent in Fig. 6b; [M(arene)L] has a maximum with $26.7 \%$ at $100 \mu \mathrm{M}$ concentration and at $\mathrm{pH}$ 5.06. With $\left[\mathrm{Ru}\left(\eta^{6} \text {-toluene }\right)\left(\mathrm{H}_{2} \mathrm{O}\right)_{3}\right]^{2+}$ the spectral changes and the extent of complex formation are even smaller than with $\left[\mathrm{Ru}\left(\eta^{6}-p \text {-cymene) }\left(\mathrm{H}_{2} \mathrm{O}\right)_{3}\right]^{2+}\right.$ (shown in Fig. S4). Additionally, the absorbance at $600 \mathrm{~nm}$ reaches only 0.015 , which makes the detection of the complex formation even more problematic. The formation of the half-sandwich $\mathrm{Rh}\left(\eta^{5}-\mathrm{C}_{5} \mathrm{Me}_{5}\right)$ complex of phthiocol is also observable at $600 \mathrm{~nm}$ and the absorbance changes are negligible for this system $(\Delta \mathrm{A}$ $\sim 0.015$, see Fig. 7) (see Fig. 8).
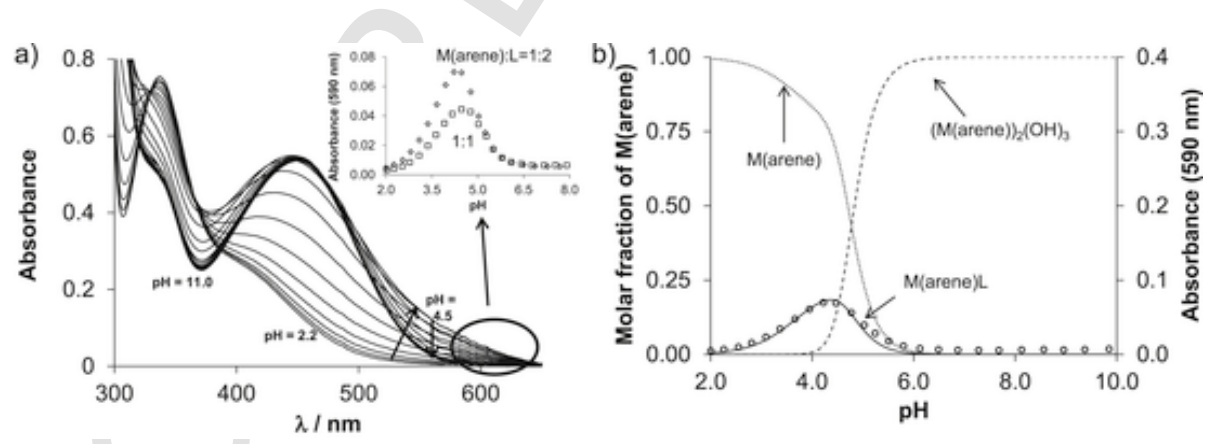

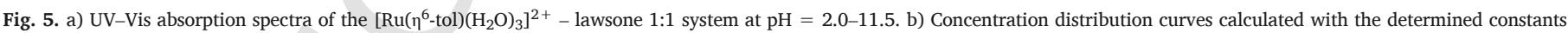
from Table 3. Absorbance at $590 \mathrm{~nm}(\mathrm{O})$ shows the complex formation $\left\{c(\right.$ lawsone $)=c\left(\left[\mathrm{Ru}\left(\eta^{6}-\mathrm{tol}^{6}\left(\mathrm{H}_{2} \mathrm{O}\right)_{3}\right]^{2+}\right)=200 \mu \mathrm{M} ; I=0.2 \mathrm{M}(\mathrm{KCl}) ; T=25.0{ }^{\circ} \mathrm{C} ; l=2 \mathrm{~cm}\right\}$.
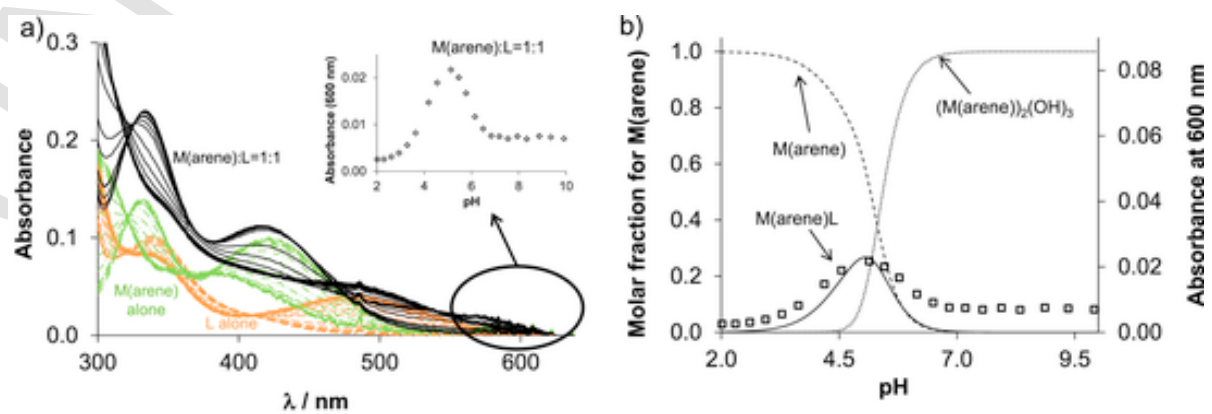

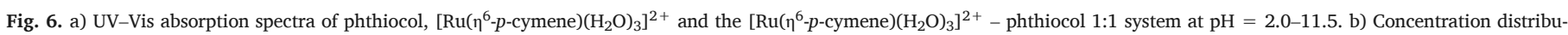

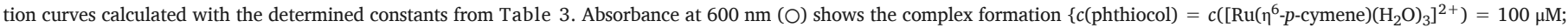
$\left.I=0.2 \mathrm{M}(\mathrm{KCl}) ; T=25.0^{\circ} \mathrm{C} ; l=2 \mathrm{~cm}\right\}$. 

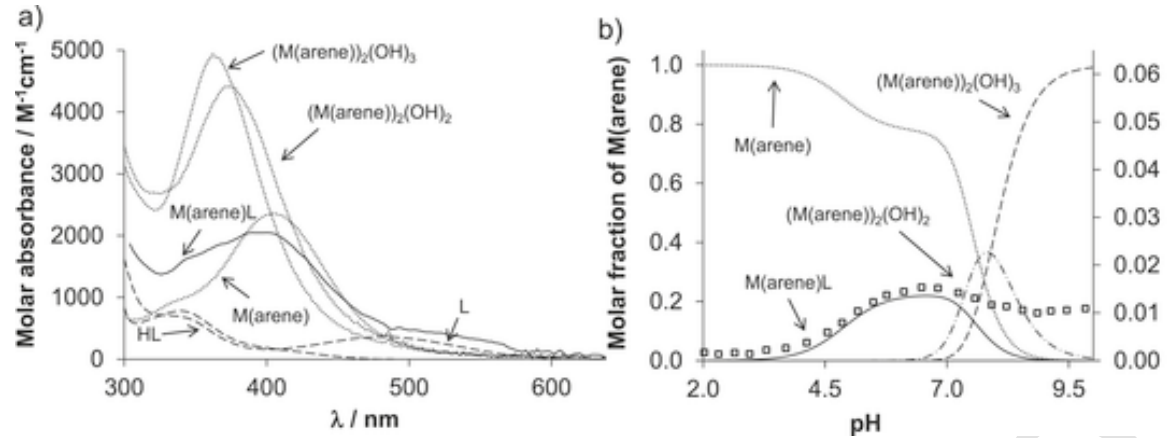

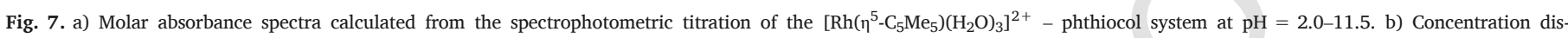

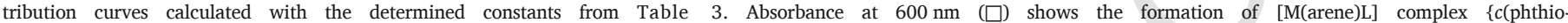
col $\left.)=c\left(\left[\mathrm{Rh}\left(\eta^{5}-\mathrm{C}_{5} \mathrm{Me}_{5}\right)\left(\mathrm{H}_{2} \mathrm{O}\right)_{3}\right]^{2+}\right)=100 \mu \mathrm{M} ; I=0.2 \mathrm{M}(\mathrm{KCl}) ; T=25.0{ }^{\circ} \mathrm{C} ; l=1 \mathrm{~cm}\right\}$.

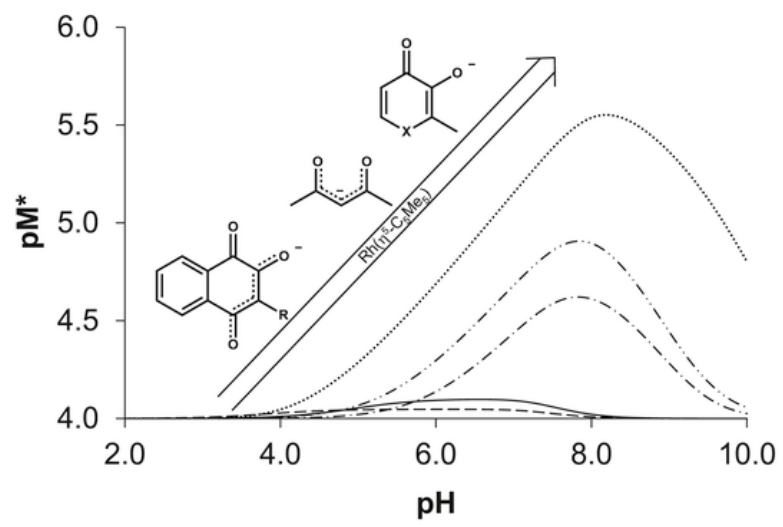

Fig. 8. Calculated $\mathrm{pM}^{*}$-curves obtained for the $\left[\mathrm{Rh}\left(\eta^{5}-\mathrm{C}_{5} \mathrm{Me}_{5}\right)\left(\mathrm{H}_{2} \mathrm{O}\right)_{3}\right]^{2+}-(\mathrm{O}, \mathrm{O})$ bidentate ligand systems plotted against the $\mathrm{pH}$. L = lawsone (- - -); phthiocol (-); acety-

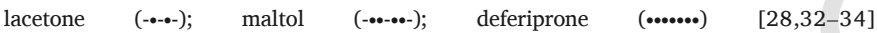
$\left\{c(\mathrm{~L})=c\left(\left[\mathrm{Rh}\left(\eta^{5}-\mathrm{C}_{5} \mathrm{Me}_{5}\right)\left(\mathrm{H}_{2} \mathrm{O}\right)_{3}\right]^{2+}\right)=100 \mu \mathrm{M} ; T=25.0{ }^{\circ} \mathrm{C} ; I=0.2 \mathrm{M}(\mathrm{KCl})\right\}$.

Comparison of the stability constants for both ligands shows a clear trend. The stability constant is the highest for $\mathrm{Ru}\left(\eta^{6}-p\right.$-cymene) complexes, which is followed by $\mathrm{Ru}\left(\eta^{6}\right.$-toluene) and the $\mathrm{Rh}\left(\eta^{5}-\mathrm{C}_{5} \mathrm{Me}_{5}\right)$ complexes have the lowest stability constants (Table 3 ). The same tendency has been found previously in the case of other $(O, O)$ donor bidentate ligands [33]. Based on the determined stability constants (Table 3 ) the calculated concentration distribution curves show different characteristics for the $\left[\mathrm{Rh}\left(\eta^{5}-\mathrm{C}_{5} \mathrm{Me}_{5}\right)\left(\mathrm{H}_{2} \mathrm{O}\right)_{3}\right]^{2+}-$ phthiocol (1:1) system (Fig. 7b); namely the complex is present in a wider range $(>5 \%$ at $\mathrm{pH} 4.4-8.0$ ) than the ruthenium analogues $(>5 \%$ at $\mathrm{pH} 3.8-6.0$ ). For the interpretation of the biological activity data, Table 3 shows the amount of the $[\mathrm{M}($ arene)L] complex formed at $\mathrm{pH}=7.4$. It can be concluded that only the $\left[\mathrm{Rh}\left(\eta^{5}-\mathrm{C}_{5} \mathrm{Me}_{5}\right)\right.$ (phth)Cl] complex is present in the solution in more than $10 \%$ and it is the least cytotoxic of them.

Quinones and naphthoquinones are redox active molecules and their redox chemistry is well characterized [35]. As complex formation often has a great impact on the ligand's redox chemistry cyclic voltammetry (CV) was used to follow the changes of the voltammograms upon complexation in a 9:1 solvent mixture of dimethylformamide (DMF) and water due to the low solubility of the compounds in water (Fig. S5). However, variation of the metal center had only a small effect on the shape of the voltammograms, most probably as a result of the low fraction of complex formation under the applied conditions.

\subsubsection{Comparison the stability of naphthoquinone complexes with other $(O, O)$ donors}

To compare the stability of complexes of the same organometallic ion formed with ligands of different $\mathrm{p} K_{\mathrm{a}}$ values, herein a modification of the method introduced by Raymond et al. is used, namely the direct comparison of $\mathrm{pM}^{*}$ values [36]. The original $\mathrm{pM}$ is the negative logarithm of the free metal ion concentration, while $\mathrm{pM}^{*}$ is calculated for the nonbound metal ion concentration: not only the free metal ion but the hydroxido species are taken into account as well. The higher $\mathrm{pM}^{*}$ value shows higher stability. The calculated $\mathrm{pM}^{*}$ curves are shown in Fig. 8 and Fig. S6, illustrating the stability difference between the complexes of 2-hydroxy-[1,4]-naphthoquinones (Table 3), 2,4-diketonates (acetylacetone), 3-hydroxy-2-methyl-pyran-4(1H)-one (maltol) and 1,2-dimethyl-3-hydroxy-pyridin-4(1H)-one (deferiprone) $[28,32-34]$. The stability constants for the $\mathrm{Ru}\left(\eta^{6}\right.$-toluene) - deferiprone system were missing for this comparison, thus $\mathrm{pH}$-potentiometric titrations were performed in this work to determine these data, which are: $\quad \log \quad K \quad[\mathrm{M}($ arene $) \mathrm{L}]=11.74 \pm 0.08 \quad$ and $\quad \mathrm{p} K_{a}$ $[\mathrm{M}($ arene $) \mathrm{L}]=9.34 \pm 0.09$. The trend of stability is the same independently from the type of the organometallic cations: deferiprone $>$ maltol $>$ acetylacetone $>2$-hydroxy- $[1,4]$-naphthoquinones is the order in a wide $\mathrm{pH}$ range.

\section{Experimental}

\subsection{Chemicals}

All solvents were of analytical grade and used without further purification. Dry solvents were used for synthesis and stored under argon. Lawsone, menadione (Acros Organics), $\mathrm{RuCl}_{3} \times \mathrm{xH}_{2} \mathrm{O}, \mathrm{RhCl}_{3} \times \mathrm{xH}_{2} \mathrm{O}$, $\mathrm{IrCl}_{3} \times \mathrm{xH}_{2} \mathrm{O}, \mathrm{OsO}_{4}$ (Johnson Matthey), $\alpha$-terpinene (Alfa Aesar), 1,2,3,4,5-pentamethylcyclopentadiene (TCI Europe), deferiprone, $\mathrm{H}_{2} \mathrm{O}_{2}$ (30\%), KCl, $\mathrm{HCl}, \mathrm{KOH}, \mathrm{KH}-$ phthalate, NaOMe, $\mathrm{Na}_{2} \mathrm{CO}_{3}, \mathrm{KH}_{2} \mathrm{PO}_{4}$, $\mathrm{NaH}_{2} \mathrm{PO}_{4}, \mathrm{Na}_{2} \mathrm{HPO}_{4}, \mathrm{MeOH}, \mathrm{CHCl}_{3}, \mathrm{CH}_{2} \mathrm{Cl}_{2}$, DMF and DMSO (Sigma Aldrich) were purchased from commercially available suppliers. For aqueous solutions Milli-Q water was used. The exact concentrations of the metal precursor stock solutions were determined by $\mathrm{pH}$-potentiometric titrations with the aim of Hyperquad 2013 program [37], employing the stability constants for hydroxido complexes from $(I=0.2 \mathrm{M}$ $\mathrm{KCl})[27,28]$. Stock solutions of the ligands were prepared on a weight-in-volume basis. In the case of buffered samples, $20 \mathrm{mM}$ phosphate buffer was used instead of water with $\mathrm{pH}=7.40$.

For characterization of the compounds NMR spectra (Figs. S7-13) were recorded with a Bruker FT-NMR spectrometer Avance III ${ }^{\mathrm{TM}}$ $500 \mathrm{MHz}$ with an UltraShieldPlus magnet at $25^{\circ} \mathrm{C}$. The measurement frequency for proton NMR $\left({ }^{1} \mathrm{H}\right)$ was $500.10 \mathrm{MHz}$ and for carbon NMR $\left({ }^{13} \mathrm{C}\left\{{ }^{1} \mathrm{H}\right\}\right) 125.75 \mathrm{MHz} \mathrm{CDCl}_{3}$ was used as solvent. Elemental analysis for carbon, hydrogen, nitrogen, sulfur and oxygen was performed at the Microanalytical Laboratory of the University of Vienna with Eurovector EA 3000 CHNS-O elemental analyzer (2009) equipped with a high temperature pyrolysis furnace (HT, Hekatech, Germany, 2009). Thermogravimetric analysis (TGA) was carried out on a TGA/SDTA851 ${ }^{\mathrm{e}}$ in- 
strument with a Sample Robot TS0801R0 from Mettler Toledo (Figs. S14-16). The recorded TGA curves revealed thermal decomposition at $\mathrm{T}<100{ }^{\circ} \mathrm{C}$, which did not allow the determination of the water content of the samples by this method.

\section{2. pH-potentiometric measurements}

pH-potentiometric measurements determining concentrations of $\left[\mathrm{Rh}\left(\eta^{5}-\mathrm{C}_{5} \mathrm{Me}_{5}\right)\left(\mathrm{H}_{2} \mathrm{O}\right)_{3}\right]^{2+}, \quad\left[\mathrm{Ru}\left(\eta^{6}-p \text {-cymene }\right)\left(\mathrm{H}_{2} \mathrm{O}\right)_{3}\right]^{2+} \quad$ and $\left[\mathrm{Ru}\left(\eta^{6} \text {-toluene }\right)\left(\mathrm{H}_{2} \mathrm{O}\right)_{3}\right]^{2+}$ were carried out at $25.0{ }^{\circ} \mathrm{C} \pm 0.1{ }^{\circ} \mathrm{C}$ in water and at a constant ionic strength of $0.2 \mathrm{M} \mathrm{KCl}$. The titrations were performed with a carbonate-free $\mathrm{KOH}$ solution $(0.20 \mathrm{M})$. The exact concentrations of $\mathrm{HCl}$ and $\mathrm{KOH}$ solutions were determined by $\mathrm{pH}$-potentiometric titrations. An Orion710A pH-meter equipped with a Metrohm electrode (type 6.0234.100) filled with $3 \mathrm{M} \mathrm{KCl}$ and a Metrohm 665 Dosimat burette was used. The volume resolution of the burette is $0.001 \mathrm{~mL}$ and its precision is $0.002 \mathrm{~mL}$. The electrode system was calibrated to the $\mathrm{pH}=-\log \left[\mathrm{H}^{+}\right]$scale by means of blank titrations (strong acid vs. strong base: $\mathrm{HCl}$ vs. $\mathrm{KOH}$ ), as suggested by the Irving method [38]. The water ionization constant $\left(\mathrm{pK}_{\mathrm{w}}\right)$ was determined as $13.76 \pm 0.01$ at $25.0{ }^{\circ} \mathrm{C} \pm 0.1{ }^{\circ} \mathrm{C}, I=0.2 \mathrm{M}(\mathrm{KCl})[39]$. The reproducibility of the titration points included in the calculations was within $0.005 \mathrm{pH}$ units. The $\mathrm{pH}$-potentiometric titrations were performed in the $\mathrm{pH}$ range between 2.0 and 11.5. The initial volume of the samples was $5.0 \mathrm{~mL}$. The metal ion concentration was $2.0 \mathrm{mM}$. The goodness-of-fit measured in Hyperquad2013 [37] by sigma $(\sigma)$ represents the overall goodness-of-fit derived from the sum of squared residuals (calculated-experimental titration data). The model was accepted when $\sigma$ was close to one $(<1.5)$. The standard deviation of the $\log \beta$ values of species included into the model was always lower than 0.1. Samples were degassed by bubbling purified argon through them for about $10 \mathrm{~min}$ prior to the measurements and the inert gas was also passed over the solutions during the titrations. $\log \beta$ values for the various hydroxido complexes $\left[\left(\mathrm{Rh}\left(\eta^{5}-\mathrm{C}_{5} \mathrm{Me}_{5}\right)\right)_{2}(\mu-\mathrm{OH})_{\mathrm{i}}\right]^{(4-\mathrm{i})+},\left[\left(\mathrm{Ru}\left(\eta^{6}-p-c y m e n e\right)\right)_{2}(\mu-\mathrm{OH})_{\mathrm{i}}\right]^{(4-\mathrm{i})+}$ and $\left[\left(\mathrm{Ru}\left(\eta^{6} \text {-toluene }\right)\right)_{2}(\mu-\mathrm{OH})_{\mathrm{i}}\right]^{(4-\mathrm{i})+}(\mathrm{i}=2$ or $\mathrm{i}=3)$ were calculated based on the $\mathrm{pH}$-potentiometric titration data in the presence of chloride ions and were found to be in good agreement with the previously published data $[27,28]$. Stability constants for $(\mathrm{M}(\text { arene }))_{\mathrm{p}} \mathrm{L}_{q} \mathrm{H}_{\mathrm{r}}$ complexes cannot be determined by $\mathrm{pH}$-potentiometry because of solubility problems of the ligands except the case of the deferiprone complexes.

\subsection{UV-Vis spectrophotometric measurements}

An Agilent Cary 8454 diode array spectrophotometer was used to record the UV-Vis spectra in the interval $200-800 \mathrm{~nm}$. The path length was 1 or $2 \mathrm{~cm}$. Equilibrium constants (proton dissociation and stability constants) and the individual spectra of the species were calculated with the computer program PSEQUAD [40]. The spectrophotometric titrations were performed in aqueous solution on samples containing the ligands with or without the organometallic cations and the concentration of the ligands was $50-200 \mu \mathrm{M}$. The metal-to-ligand ratio was $1: 1$ in the $\mathrm{pH}$ range from 2 to 11.5 at $25.0{ }^{\circ} \mathrm{C} \pm 0.1{ }^{\circ} \mathrm{C}, \mathrm{I}=0.2 \mathrm{M}(\mathrm{KCl})$.

\subsection{Cyclic voltammetric measurements}

Electrochemical experiments of phthiocol containing samples were performed on an Autolab-PGSTAT 204 potentiostat/galvanostat and monitored with Metrohm's Nova software. Measurements of the ligand $(1 \mathrm{mM})$ in the presence and the absence of the metal ions $(1 \mathrm{mM})$ were obtained in a 9:1 DMF/water mixture because of low solubility of phthiocol. The aqueous part contained $20 \mathrm{mM}$ phosphate buffer $(\mathrm{pH}=7.40)$. The supporting electrolyte was $0.2 \mathrm{M}\left[n-\mathrm{Bu}_{4} \mathrm{~N}\right]\left[\mathrm{BF}_{4}\right] . \mathrm{A}$ three-electrode configuration cell was used with two glassy carbon electrodes: one was the working and another was the counter electrode, the reference electrode was an $\mathrm{Ag} / \mathrm{AgCl} /(1 \mathrm{M}) \mathrm{KCl}$ electrode. The system was calibrated for $0.01 \mathrm{M}$ ferrocene before every experiment and gave a potential at $+0.688 \mathrm{~V} v$ s. NHE.

\subsection{Synthesis phthiocol (Hphth)}

Menadione ( $1.00 \mathrm{~g}, 5.81 \mathrm{mmol}, 1$ eq.) was dissolved in methanol $(10 \mathrm{~mL})$ and stirred under ice cooling. $\mathrm{Na}_{2} \mathrm{CO}_{3}(0.207 \mathrm{~g}, 1.95 \mathrm{mmol}$, 0.3 eq.) and $\mathrm{H}_{2} \mathrm{O}_{2}$ solution ( $36 \%, 1 \mathrm{~mL}, 32.6 \mathrm{mmol}, 1.7$ eq.) were dissolved in $\mathrm{H}_{2} \mathrm{O}(10 \mathrm{~mL})$. The aqueous solution was added dropwise to the yellow suspension. After complete addition, the mixture was stirred at room temperature for $1 \mathrm{~h} . \mathrm{H}_{2} \mathrm{O}(100 \mathrm{~mL})$ was added to the mixture and the formed precipitate was separated by filtration and dried in vacuo. The colorless solid was suspended in water $(20 \mathrm{~mL})$ and concentrated sulfuric acid was added until complete dissolution. The dark red solution was diluted with water and extracted with dichloromethane. The organic layer was separated and extracted with saturated $\mathrm{NaHCO}_{3}$ solution. The aqueous layer was acidified with concentrated $\mathrm{HCl}$ and extracted with dichloromethane. Afterwards, the yellow solution was dried over anhydrous $\mathrm{Na}_{2} \mathrm{SO}_{4}$, evaporated and dried in vacuo. Yield: $0.788 \mathrm{~g}$ (4.19 mmol, 72\%), yellow powder. Characterization: ${ }^{1} \mathrm{H}$ NMR $\left(500.10 \mathrm{MHz}, \mathrm{CDCl}_{3}\right) \delta=2.11\left(\mathrm{~s}, 3 \mathrm{H}, \mathrm{H}_{1}\right), 7.29\left(\mathrm{~s}, 1 \mathrm{H}, \mathrm{H}_{\mathrm{OH}}\right), 7.68$ (ddd, $J=8 \mathrm{~Hz}, 1 \mathrm{~Hz}, 1 \mathrm{H}, \mathrm{H}_{6 / 7}$.), 7.75 (ddd, $J=8 \mathrm{~Hz}, 1 \mathrm{~Hz}, 1 \mathrm{H}, \mathrm{H}_{6 / 7}$.), 8.08 (dd, $J=8 \mathrm{~Hz}, 1 \mathrm{H}, \mathrm{H}_{5 / 8}$ ), 8.13 (dd, $J=8 \mathrm{~Hz}, 1 \mathrm{H}, \mathrm{H}_{5 / 8}$ ).

\subsection{Synthesis of dimeric metal precursors}

The dimeric metal precursors $\left[\mathrm{RuCl}_{2}\left(\eta^{6}-p \text {-cymene }\right)\right]_{2} \quad[41]$, $\left[\mathrm{RuCl}_{2}\left(\eta^{6} \text {-tolouene }\right)\right]_{2} \quad[42], \quad\left[\mathrm{RuBr}_{2}\left(\eta^{6}-p \text {-cymene }\right)\right]_{2} \quad$ [43], $\left[\operatorname{RuI}_{2}\left(\eta^{6}-p \text {-cymene }\right)\right]_{2} \quad[43], \quad\left[\mathrm{RhCl}_{2}\left(\eta^{5}-\mathrm{C}_{5} \mathrm{Me}_{5}\right)\right]_{2} \quad[44] \quad$ and $\left[\mathrm{OsCl}_{2}\left(\eta^{6} \text {-p-cymene }\right)\right]_{2}[45]$ were synthesized according to literature.

\subsection{General procedure}

Phthiocol (3 eq.) and sodium methoxide (3.2 eq.) were dissolved in dry methanol $(12 \mathrm{~mL})$ and stirred for $10 \mathrm{~min}$. Afterwards, the respective metal precursor dimer (1 eq.) was added to the dark red mixture. Depending on the desired complex, two different methods were applied. Method A: The mixture was stirred at room temperature or at $40{ }^{\circ} \mathrm{C}$ for $2-24 \mathrm{~h}$. Method B: The mixture was stirred at $40-50{ }^{\circ} \mathrm{C}$ under microwave irradiation for 6-14 min. In both methods, the purification procedure was conducted in the same way. The precipitate was separated from the supernatant, which was further evaporated. The solid were dissolved in dichloromethane, filtrated, and the solvent was evaporated. The remaining black residues were combined, dissolved in dichloromethane and $n$-hexane was added until precipitation started. The mixture was cooled to ensure complete crystallization of the desired complexes. The black crystals were separated and dried in vacuo. Minor changes to the general procedure are described in the respective synthesis. ${ }^{1} \mathrm{H}$ NMR spectra recorded for complexes are shown in Figs. S7-13 with the general numbering scheme for clarity (Chart S1).

\subsubsection{Synthesis of $R u\left(\eta^{6}-p\right.$-cymene) (phth)Cl](1)}

The synthesis of complex 1 was introduced earlier [14] and the reaction was performed according to this procedure (method A), using $\left[\mathrm{Ru}\left(\eta^{6}-p \text {-cym }\right) \mathrm{Cl}_{2}\right]_{2}$ (150 mg, $0.24 \mathrm{mmol}, 1$ eq.), Hphth (135 mg, $0.72 \mathrm{mmol}, 3$ eq.) and sodium methoxide ( $42 \mathrm{mg}, 0.77 \mathrm{mmol}, 3.2$ eq.). The mixture was stirred at room temperature for $2 \mathrm{~h}$. Yield: $122 \mathrm{mg}$ (0.27 mmol, 56\%), black crystals. ${ }^{1} \mathrm{H}$ NMR: $\left(500.10 \mathrm{MHz}, \mathrm{CDCl}_{3}\right)$ $\delta=1.41\left(\mathrm{~d}, J=7 \mathrm{~Hz}, 3 \mathrm{H}, \mathrm{H}_{\mathrm{g}}\right), 1.43\left(\mathrm{~d}, J=7 \mathrm{~Hz}, 3 \mathrm{H}, \mathrm{H}_{\mathrm{g}}\right), 2.10(\mathrm{~s}, 3 \mathrm{H}$, $\mathrm{H}_{1}$ ), 2.41 (s, $3 \mathrm{H}, \mathrm{H}_{\mathrm{e}}$ ), 2.96-3.03 (m, $\left.1 \mathrm{H}, \mathrm{H}_{\mathrm{f}}\right), 5.48\left(\mathrm{~d}, J=6 \mathrm{~Hz}, 2 \mathrm{H}, \mathrm{H}_{\mathrm{b}}\right.$ ), $5.75\left(\mathrm{~d}, J=5 \mathrm{~Hz}, 2 \mathrm{H}, \mathrm{H}_{\mathrm{c}}\right), 7.52\left(\mathrm{dd}, J=8 \mathrm{~Hz}, J=8 \mathrm{~Hz}, 1 \mathrm{H}, \mathrm{H}_{8}\right), 7.68$ (dd, $J=8 \mathrm{~Hz}, J=8 \mathrm{~Hz}, 1 \mathrm{H}, \mathrm{H}_{5}$ ), 7.94-7.99 (m, 2H, $\mathrm{H}_{6 / 7}$ ). 
${ }^{13} \mathrm{C}$ NMR (125.76 MHz, $\left.\mathrm{CDCl}_{3}\right) \delta=196.1\left(\mathrm{C}_{1}\right), 183.4\left(\mathrm{C}_{4}\right), 169.3\left(\mathrm{C}_{3}\right)$, $136.1\left(\mathrm{C}_{8}\right), 133.0\left(\mathrm{C}_{4 \mathrm{a}}\right), 131.4\left(\mathrm{C}_{5}\right), 128.1\left(\mathrm{C}_{8 \mathrm{a}}\right), 126.6\left(\mathrm{C}_{7}\right), 126.5\left(\mathrm{C}_{6}\right)$, $123.5\left(\mathrm{C}_{2}\right), 100.7\left(\mathrm{C}_{\mathrm{d}}\right), 96.8\left(\mathrm{C}_{\mathrm{a}}\right), 82.1\left(\mathrm{C}_{\mathrm{c}}\right), 81.1\left(\mathrm{C}_{\mathrm{c}}\right), 79.5\left(\mathrm{C}_{\mathrm{b}}\right), 78.5$ $\left(\mathrm{C}_{\mathrm{b}}\right), 31.6\left(\mathrm{C}_{\mathrm{f}}\right), 22.6\left(\mathrm{C}_{\mathrm{g}}\right), 22.6\left(\mathrm{C}_{\mathrm{g}}\right), 18.8\left(\mathrm{C}_{\mathrm{e}}\right), 9.0\left(\mathrm{C}_{1}\right)$. Anal. Calc. for $\mathrm{C}_{21} \mathrm{H}_{21} \mathrm{ClO}_{3} \mathrm{Ru} \cdot 0.2 \mathrm{H}_{2} \mathrm{O}$ : C $54.65 \%, \mathrm{H} 4.67 \%$, O $11.09 \%$. Found: $\mathrm{C}$ $54.52 \%$, H 4.56\%, N < 0.05\% S < 0.02\%, O 11.07\%.

\subsubsection{Synthesis of $\left[R u\left(\eta^{6}-p\right.\right.$-cymene)(phth)Br](2)}

The reaction was performed according to method $\mathrm{B}$, using compound $\left[\operatorname{RuBr}_{2}\left(\eta^{6}-p \text {-cymene }\right)\right]_{2}(150 \mathrm{mg}, 0.19 \mathrm{mmol}, 1$ eq.), Hphth $(107 \mathrm{mg}$, $0.57 \mathrm{mmol}, 3$ eq.) and sodium methoxide ( $33 \mathrm{mg}, 0.61 \mathrm{mmol}, 3.2 \mathrm{eq}$.). The mixture was stirred under microwave irradiation at $50{ }^{\circ} \mathrm{C}$ for $15 \mathrm{~min}$ (10-20 W). Yield: $126 \mathrm{mg}(0.25 \mathrm{mmol}, 66 \%)$, black crystals. ${ }^{1} \mathrm{H}$ NMR $\left(500.10 \mathrm{MHz}, \mathrm{CDCl}_{3}\right) \delta=1.41$ (d, $\left.J=7 \mathrm{~Hz}, 3 \mathrm{H}, \mathrm{H}_{\mathrm{f}}\right), 1.44$ (d, $J=7 \mathrm{~Hz}$, $3 \mathrm{H}, \mathrm{H}_{\mathrm{f}}$ ), 2.08 (s, 3H, $\mathrm{H}_{1}$ ), 2.41 (s, 3H, $\mathrm{H}_{\mathrm{e}}$ ), 3.01 (hept, $J=7 \mathrm{~Hz}, 1 \mathrm{H}$, $\left.\mathrm{H}_{\mathrm{g}}\right), 5.48\left(\mathrm{~d}, J=6 \mathrm{~Hz}, 1 \mathrm{H}, \mathrm{H}_{\mathrm{b}}\right), 5.50\left(\mathrm{~d}, J=6 \mathrm{~Hz}, 1 \mathrm{H}, \mathrm{H}_{\mathrm{b}}\right), 5.74(\mathrm{~d}$, $\left.J=6 \mathrm{~Hz}, 1 \mathrm{H}, \mathrm{H}_{\mathrm{c}}\right), 5.77\left(\mathrm{~d}, J=6 \mathrm{~Hz}, 1 \mathrm{H}, \mathrm{H}_{\mathrm{c}}\right), 7.52(\mathrm{dd}, J=8 \mathrm{~Hz}$, $\left.J=8 \mathrm{~Hz}, 1 \mathrm{H}, \mathrm{H}_{8}\right), 7.68\left(\mathrm{dd}, J=8 \mathrm{~Hz}, J=8 \mathrm{~Hz}, 1 \mathrm{H}, \mathrm{H}_{5}\right), 7.94-8.00$ (m, $\left.2 \mathrm{H}, \mathrm{H}_{6 / 7}\right) .{ }^{13} \mathrm{C}$ NMR $\left(125.76 \mathrm{MHz}, \mathrm{CDCl}_{3}\right) \delta=196.2\left(\mathrm{C}_{1}\right), 183.3$ $\left(\mathrm{C}_{4}\right), 169.4\left(\mathrm{C}_{3}\right), 136.1\left(\mathrm{C}_{8}\right), 132.9\left(\mathrm{C}_{4 \mathrm{a}}\right), 131.4\left(\mathrm{C}_{5}\right), 128.0\left(\mathrm{C}_{8 \mathrm{a}}\right), 126.5$ $\left(\mathrm{C}_{7}\right), 126.5\left(\mathrm{C}_{6}\right) 123.5\left(\mathrm{C}_{2}\right), 100.9\left(\mathrm{C}_{\mathrm{d}}\right), 96.5\left(\mathrm{C}_{\mathrm{a}}\right), 82.3\left(\mathrm{C}_{\mathrm{c}}\right), 80.8\left(\mathrm{C}_{\mathrm{c}}\right)$, $80.3\left(\mathrm{C}_{\mathrm{b}}\right), 78.6\left(\mathrm{C}_{\mathrm{b}}\right), 31.7\left(\mathrm{C}_{\mathrm{f}}\right), 22.7\left(\mathrm{C}_{\mathrm{g}}\right), 22.6\left(\mathrm{C}_{\mathrm{g}}\right), 19.0\left(\mathrm{C}_{\mathrm{e}}\right), 8.9\left(\mathrm{C}_{1}\right)$ ). Anal. Calc. for $\mathrm{C}_{21} \mathrm{H}_{21} \mathrm{BrO}_{3} \mathrm{Ru}$ : C $50.21 \%$, H $4.21 \%$, O 9.55\%. Found: $\mathrm{C}$ $49.90 \%, \mathrm{H} 4.07 \%, \mathrm{~N}<0.05 \%, \mathrm{~S}<0.02 \%$, O $9.80 \%$.

\subsubsection{Synthesis of $\left[R u\left(\eta^{6}-p\right.\right.$-cymene)(phth)I](3)}

The reaction was performed according to method A, using $\left[\mathrm{RuI}_{2}\left(\eta^{6}-p \text {-cymene }\right)\right]_{2}(120 \mathrm{mg}, 0.12 \mathrm{mmol}, 1 \mathrm{eq}$ ), Hphth (68 mg, $0.36 \mathrm{mmol}, 3$ eq.) and sodium methoxide ( $21 \mathrm{mg}, 0.61 \mathrm{mmol}, 3.2 \mathrm{eq}$.). The mixture was stirred at $40{ }^{\circ} \mathrm{C}$ for $23 \mathrm{~h}$. Yield: $96 \mathrm{mg}(0.17 \mathrm{mmol}$, $71 \%$ ), black crystals. ${ }^{1} \mathrm{H}$ NMR $\left(500.10 \mathrm{MHz}, \mathrm{CDCl}_{3}\right) \delta=1.42$ (d, $J=7 \mathrm{~Hz}, 3 \mathrm{H}, \mathrm{H}_{\mathrm{g}}$ ), 1.45 (d, $J=7 \mathrm{~Hz}, 3 \mathrm{H}, \mathrm{H}_{\mathrm{g}}$ ), $2.05\left(\mathrm{~s}, 3 \mathrm{H}, \mathrm{H}_{1}\right.$ ), 2.41 (s, $3 \mathrm{H}, \mathrm{H}_{\mathrm{e}}$ ), 2.97-3.07 (m, $\left.1 \mathrm{H}, \mathrm{H}_{\mathrm{f}}\right), 5.50\left(\mathrm{~d}, J=6 \mathrm{~Hz}, 1 \mathrm{H}, \mathrm{H}_{\mathrm{b}}\right), 5.58$ $\left(\mathrm{d}, J=6 \mathrm{~Hz}, 1 \mathrm{H}, \mathrm{H}_{\mathrm{b}}\right), 5.76\left(\mathrm{~d}, J=6 \mathrm{~Hz}, 1 \mathrm{H}, \mathrm{H}_{\mathrm{c}}\right), 5.84(\mathrm{~d}, J=5.8$, $1 \mathrm{H}, \mathrm{H}_{\mathrm{c}}$ ) $7.52\left(\mathrm{dd}, J=8 \mathrm{~Hz}, J=8 \mathrm{~Hz}, 1 \mathrm{H}, \mathrm{H}_{8}\right), 7.69(\mathrm{dd}, J=8 \mathrm{~Hz}$, $\left.J=8 \mathrm{~Hz}, 1 \mathrm{H}, \mathrm{H}_{5}\right), 7.92-8.01\left(\mathrm{~m}, 2 \mathrm{H}, \mathrm{H}_{6 / 7}\right) .{ }^{13} \mathrm{C} \mathrm{NMR}(125.76 \mathrm{MHz}$, $\left.\mathrm{CDCl}_{3}\right) \delta=196.2\left(\mathrm{C}_{1}\right), 183.3\left(\mathrm{C}_{4}\right), 169.6\left(\mathrm{C}_{3}\right), 136.0\left(\mathrm{C}_{5}\right), 132.8\left(\mathrm{C}_{2}\right)$, $131.4\left(\mathrm{C}_{8}\right), 127.9\left(\mathrm{C}_{8 \mathrm{a}}\right), 126.5\left(\mathrm{C}_{6 / 7}\right), 126.4\left(\mathrm{C}_{6 / 7}\right), 123.4\left(\mathrm{C}_{4 \mathrm{a}}\right), 101.0$ $\left(\mathrm{C}_{\mathrm{d}}\right), 96.0\left(\mathrm{C}_{\mathrm{a}}\right), 82.7\left(\mathrm{C}_{\mathrm{c}}\right), 81.6\left(\mathrm{C}_{\mathrm{c}}\right), 80.7\left(\mathrm{C}_{\mathrm{b}}\right), 79.1\left(\mathrm{C}_{\mathrm{b}}\right), 31.8\left(\mathrm{C}_{\mathrm{f}}\right), 22.8$ $\left(\mathrm{C}_{\mathrm{g}}\right), 22.7\left(\mathrm{C}_{\mathrm{g}}\right), 19.3\left(\mathrm{C}_{\mathrm{e}}\right), 8.9\left(\mathrm{C}_{1}\right)$ ). Anal. Calc. for $\mathrm{C}_{21} \mathrm{H}_{21} \mathrm{IO}_{3} \mathrm{Ru} \cdot 0.1 \mathrm{H}_{2} \mathrm{O}$ : C $45.76 \%$, H $3.88 \%$, O 9.00\%. Found: C $45.43 \%$, H 3.86\%, N < 0.05\% $\mathrm{S}<0.02 \%$, O $8.66 \%$.

\subsubsection{Synthesis of $\left[R u\left(\eta^{6}\right.\right.$-toluene)(phth)Cl](4)}

The reaction was performed according to method B, using Hphth ( $85 \mathrm{mg}, 0.454 \mathrm{mmol}, 2.4$ eq.) and sodium methoxide (27 mg, $0.491 \mathrm{mmol}, 2.6 \mathrm{eq}$.). They were dissolved in $6 \mathrm{~mL}$ dry methanol and stirred for $10 \mathrm{~min}$ at room temperature. $\left[\mathrm{Ru}\left(\eta^{6} \text {-toluene }\right) \mathrm{Cl}_{2}\right]_{2}(100 \mathrm{mg}$, $0.189 \mathrm{mmol}, 1$ eq.) was added and the mixture was stirred under microwave irradiation at $40{ }^{\circ} \mathrm{C}$ for $7 \mathrm{~min}$. Afterwards, the dark mixture was stored in the fridge overnight for complete precipitation. The black solid was separated, washed twice with $2 \mathrm{~mL}$ ice cold methanol, twice with $4 \mathrm{~mL} n$-hexane and dried in vacuo. $141 \mathrm{mg}(0.339 \mathrm{mmol}, 90 \%) .{ }^{1} \mathrm{H}$ NMR $\left(500.10 \mathrm{MHz}, \mathrm{CDCl}_{3}\right.$ ) $\delta=7.99$ (ddd, $J=7.6,4.0,1.2 \mathrm{~Hz}, 2 \mathrm{H}$ ), 7.69 (ddd, $J=7.6,1.3 \mathrm{~Hz}, 1 \mathrm{H}$ ), 7.53 (ddd, $J=7.6,1.3 \mathrm{~Hz}, 1 \mathrm{H}$ ), $6.01-5.96$ (m, 2H), 5.71 (t, $J=5.6 \mathrm{~Hz}, 1 \mathrm{H}), 5.50-5.47$ (m, 2H), 2.41 (s, 3H), 2.11 (s, 3H). ${ }^{13} \mathrm{C}$ NMR $\left(151 \mathrm{MHz}, \mathrm{CDCl}_{3}\right) \delta 196.5\left(\mathrm{C}_{1}\right), 183.5\left(\mathrm{C}_{4}\right), 169.2\left(\mathrm{C}_{2}\right)$, 136.3( $\left.\mathrm{C}_{6 / 7}\right), 132.9\left(\mathrm{C}_{8 \mathrm{a} / 4 \mathrm{a}}\right), 131.5\left(\mathrm{C}_{6 / 7}\right), 128.1\left(\mathrm{C}_{8 \mathrm{a} / 4 \mathrm{a}}\right), 126.6\left(2 \mathrm{xC}_{5 /}\right.$ 8), $123.9\left(\mathrm{C}_{3}\right), 99.9\left(\mathrm{C}_{\mathrm{a}}\right), 86.4\left(\mathrm{C}_{\mathrm{c}}\right), 85.7\left(\mathrm{C}_{\mathrm{c}}\right), 78.3\left(\mathrm{C}_{\mathrm{b}}\right), 75.9\left(\mathrm{C}_{\mathrm{b}}\right)$, $19.17\left(\mathrm{C}_{\mathrm{g}}\right), 9.0\left(\mathrm{C}_{1}\right)$. Anal. Calc. for $\mathrm{C}_{16} \mathrm{H}_{15} \mathrm{ClO}_{3} \mathrm{Ru} \cdot 0.1 \mathrm{H}_{2} \mathrm{O}: \mathrm{C} 51.77 \%, \mathrm{H}$ $3.67 \%, \mathrm{~N}<0.05 \% \mathrm{~S}<0.02 \%$, O $11.88 \%$. Found: C 51.47\%, H 3.54\%, $\mathrm{N}<0.05 \% \mathrm{~S}<0.02 \%$, O $12.22 \%$.

\subsubsection{Synthesis of $\left[O s\left(\eta^{6}-p\right.\right.$-cymene)(phth)Cl](5)}

The reaction was performed according to method A, using [Os( $\eta^{6}-p$-cymene $\left.) \mathrm{Cl}_{2}\right]_{2}$ (126 mg, $0.159 \mathrm{mmol}, 1$ eq.), Hphth (63 mg, $0.335 \mathrm{mmol}, 2.2$ eq.) and sodium methoxide (21 mg, $0.382 \mathrm{mmol}, 2.4$ eq.). The mixture was stirred at $40^{\circ} \mathrm{C}$ for $1.5 \mathrm{~h}$. Yield: $26 \mathrm{mg}$ (0.048 mmol, 15\%), black crystals. ${ }^{1} \mathrm{H}$ NMR $\left(500.10 \mathrm{MHz}, \mathrm{CDCl}_{3}\right)$ $\delta=1.37\left(\mathrm{~d}, J=7 \mathrm{~Hz}, 3 \mathrm{H}, \mathrm{H}_{\mathrm{g}}\right), 1.39\left(\mathrm{~d}, J=7 \mathrm{~Hz}, 3 \mathrm{H}, \mathrm{H}_{\mathrm{g}}\right), 2.15$ (s, $3 \mathrm{H}, \mathrm{H}_{1}$ ), 2.44 (s, 3H, $\mathrm{H}_{\mathrm{e}}$ ), 2.79-2.89 (m, $\left.1 \mathrm{H}, \mathrm{H}_{\mathrm{f}}\right), 5.93(\mathrm{~d}, J=5 \mathrm{~Hz}$, $\left.1 \mathrm{H}, \mathrm{H}_{\mathrm{b}}\right), 5.96\left(\mathrm{~d}, J=5 \mathrm{~Hz}, 1 \mathrm{H}, \mathrm{H}_{\mathrm{b}}\right), 6.22\left(\mathrm{~d}, J=5 \mathrm{~Hz}, 1 \mathrm{H}, \mathrm{H}_{\mathrm{c}}\right), 6.25$ (d, $J=5 \mathrm{~Hz}, 1 \mathrm{H}, \mathrm{H}_{\mathrm{c}}$ ) 7.55 (dd, $J=8 \mathrm{~Hz}, J=8 \mathrm{~Hz}, 1 \mathrm{H}, \mathrm{H}_{8}$ ), 7.73 (dd, $\left.J=8 \mathrm{~Hz}, J=8 \mathrm{~Hz}, 1 \mathrm{H}, \mathrm{H}_{5}\right), 8.00-8.04\left(\mathrm{~m}, 2 \mathrm{H}, \mathrm{H}_{6 / 7}\right) .{ }^{13} \mathrm{C} \mathrm{NMR}$ $\left(125.76 \mathrm{MHz}, \mathrm{CDCl}_{3}\right) \delta=198.0\left(\mathrm{C}_{1}\right), 183.5\left(\mathrm{C}_{4}\right), 170.2\left(\mathrm{C}_{3}\right), 136.4$ $\left(\mathrm{C}_{5}\right), 133.0\left(\mathrm{C}_{2}\right), 131.6\left(\mathrm{C}_{8}\right), 128.0\left(\mathrm{C}_{8 \mathrm{a}}\right), 126.8\left(\mathrm{C}_{6 / 7}\right), 126.7\left(\mathrm{C}_{6 / 7}\right)$, $124.2\left(\mathrm{C}_{4 \mathrm{a}}\right), 91.3\left(\mathrm{C}_{\mathrm{d}}\right), 88.2\left(\mathrm{C}_{\mathrm{a}}\right), 73.7\left(\mathrm{C}_{\mathrm{c}}\right), 72.7\left(\mathrm{C}_{\mathrm{c}}\right), 70.3\left(\mathrm{C}_{\mathrm{b}}\right), 69.3$ $\left(\mathrm{C}_{\mathrm{b}}\right), 32.3\left(\mathrm{C}_{\mathrm{f}}\right), 23.0\left(\mathrm{C}_{\mathrm{g}}\right), 22.9\left(\mathrm{C}_{\mathrm{g}}\right), 19.2\left(\mathrm{C}_{\mathrm{e}}\right), 9.0\left(\mathrm{C}_{1}\right)$. Anal. Calc. for $\mathrm{C}_{21} \mathrm{H}_{21} \mathrm{ClO}_{3} \mathrm{Os} \cdot 0.5 \mathrm{H}_{2} \mathrm{O}$ : C $45.36 \%$, H $3.99 \%$, O $10.07 \%$. Found: $\mathrm{C}$ $45.07 \%$, H $3.98 \%$, N $0.07 \%$, O $9.67 \%$.

\subsubsection{Synthesis of $\left[R h\left(\eta^{5}-C_{5} M e_{5}\right)\right.$ (phth)Cl](6)}

The reaction was performed according to method $\mathrm{B}$, using compound $\left[\mathrm{RhCl}_{2}\left(\eta^{5}-\mathrm{C}_{5} \mathrm{Me}_{5}\right)\right]_{2}(100 \mathrm{mg}, 0.16 \mathrm{mmol}, 1 \mathrm{eq}$.$) , Hphth (90 \mathrm{mg}$, $0.48 \mathrm{mmol}, 3$ eq.) and sodium methoxide ( $28 \mathrm{mg}, 0.51 \mathrm{mmol}, 3.2 \mathrm{eq}$.). The mixture was stirred under microwave irradiation at $50{ }^{\circ} \mathrm{C}$ for $6 \mathrm{~min}$ (10-20 W). Yield: $111 \mathrm{mg}(0.24 \mathrm{mmol}, 75 \%)$, black crystals. ${ }^{1} \mathrm{H}$ NMR $\left(500.10 \mathrm{MHz}, \mathrm{CDCl}_{3}\right) \delta=1.79\left(\mathrm{~s}, 15 \mathrm{H}, \mathrm{H}_{\mathrm{b}}\right), 2.10$ (s, 3H, $\mathrm{H}_{1}$ ) $), 7.49$ (ddd, $J=8 \mathrm{~Hz}, J=7 \mathrm{~Hz}, J=1 \mathrm{~Hz}, 1 \mathrm{H}, \mathrm{H} 7$ ), 7.67 (ddd, $J=8 \mathrm{~Hz}, J=8 \mathrm{~Hz}$, $\left.J=1 \mathrm{~Hz}, 1 \mathrm{H}, \mathrm{H}_{6}\right), 7.96-8.02\left(\mathrm{~m}, 2 \mathrm{H}, \mathrm{H}_{5 / 8}\right) .{ }^{13} \mathrm{C}$ NMR $(125.76 \mathrm{MHz}$, $\left.\mathrm{CDCl}_{3}\right) \delta=194.2\left(\mathrm{C}_{1}\right), 183.7\left(\mathrm{C}_{4}\right), 169.2\left(\mathrm{C}_{3}\right), 135.7\left(\mathrm{C}_{6}\right), 133.6\left(\mathrm{C}_{4 \mathrm{a}}\right)$, $131.2\left(\mathrm{C}_{7}\right), 129.2\left(\mathrm{C}_{8 \mathrm{a}}\right), 126.4\left(\mathrm{C}_{8}\right), 126.4\left(\mathrm{C}_{5}\right), 122.6\left(\mathrm{C}_{2}\right), 93.1\left(\mathrm{C}_{\mathrm{a}}\right)$, $9.2\left(\mathrm{C}_{\mathrm{b}}\right), 9.2\left(\mathrm{C}_{1}\right)$. Anal. Calc. for $\mathrm{C}_{21} \mathrm{H}_{22} \mathrm{ClO}_{3} \mathrm{Rh} \cdot 0.1 \mathrm{H}_{2} \mathrm{O}: \mathrm{C} 54.53 \%, \mathrm{H}$ $4.84 \%, \mathrm{~N}<0.05 \% \mathrm{~S}<0.02 \%$, O $10.72 \%$. Found: C 54.15\%, H 4.75\%, $\mathrm{N}<0.05 \% \mathrm{~S}<0.02 \%$, O $10.34 \%$.

\subsubsection{Synthesis of $\left[R u\left(\eta^{6}-p-c y m e n e\right)(l a w) C l\right](7)$}

The complex of lawsone was synthesized according to method A. A solution of $\left[\mathrm{Ru}\left(\eta^{6}-p \text {-cymene }\right) \mathrm{Cl}_{2}\right]_{2}(200 \mathrm{mg}, 0.33 \mathrm{mmol}, 1$ eq.) in $\mathrm{CH}_{2} \mathrm{Cl}_{2}(10 \mathrm{~mL})$ was added to a solution of Hlaw $(124 \mathrm{mg}, 0.73 \mathrm{mmol}$, 2 eq.) and sodium methoxide ( $43 \mathrm{mg}, 0.80 \mathrm{mmol}, 2.2$ eq.) in methanol $(15 \mathrm{~mL})$. The reaction mixture was stirred at room temperature and under argon atmosphere for $3 \mathrm{~h}$. The reaction mixture was filtered and solvent was evaporated under reduced pressure. The residue (deep violet solid) was extracted with dichloromethane and concentrated. The solid was dissolved in $2 \mathrm{~mL} \mathrm{MeOH}$ and precipitated by addition of ether and n-hexane. Yield: $202 \mathrm{mg}(0.455 \mathrm{mmol}, 69 \%) .{ }^{1} \mathrm{H}$ NMR $(500.10 \mathrm{MHz}$, $\mathrm{CDCl}_{3}$ ): $\delta 1.41\left(\mathrm{dd}, J=6.9,2.4 \mathrm{~Hz}, 6 \mathrm{H}, \mathrm{H}_{\mathrm{g}}\right), 2.40\left(\mathrm{~s}, 3 \mathrm{H}, \mathrm{H}_{\mathrm{e}}\right), 3.00$ (hept, $J=6.7 \mathrm{~Hz}, 1 \mathrm{H}, \mathrm{H}_{\mathrm{f}}$ ), 5.53-5.49 (m, 2H), 5.80-5.74 (m, 2H), 6.13 (s, $1 \mathrm{H}, \mathrm{H}_{1}$ ), 7.58 (ddd, $J=7.6,1.2 \mathrm{~Hz}, 1 \mathrm{H}, \mathrm{H}_{6 / 7}$ ), 7.75 (ddd, $J=7.6$, $\left.1.3 \mathrm{~Hz}, 1 \mathrm{H}, \mathrm{H}_{6 / 7}\right), 8.04-7.99\left(\mathrm{~m}, 2 \mathrm{H}, \mathrm{H}_{5 / 8}\right) .{ }^{13} \mathrm{C} \mathrm{NMR}\left(126 \mathrm{MHz}, \mathrm{CDCl}_{3}\right.$ )

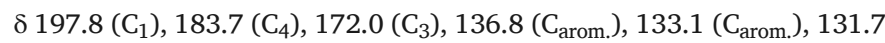
( $\mathrm{C}_{\text {arom. }}$ ), 128.3 ( $\left.\mathrm{C}_{\text {arom. }}\right), 127.0$ ( $\left.\mathrm{C}_{\text {arom. }}\right), 126.7$ ( $\left.\mathrm{C}_{\text {arom. }}\right), 113.0\left(\mathrm{C}_{2}\right), 101.3$ $\left(\mathrm{C}_{\mathrm{d}}\right), 96.8\left(\mathrm{C}_{\mathrm{a}}\right), 81.4\left(2 \mathrm{xC}_{\mathrm{c}}\right), 79.2\left(2 \mathrm{xC}_{\mathrm{b}}\right), 31.6\left(\mathrm{C}_{\mathrm{f}}\right), 22.6\left(2 \mathrm{xC}_{\mathrm{g}}\right), 19.0$ $\left(\mathrm{C}_{\mathrm{e}}\right.$ ). Anal. Calc. for $\mathrm{C}_{20} \mathrm{H}_{19} \mathrm{ClO}_{3} \mathrm{Ru} \cdot 0.25 \mathrm{H}_{2} \mathrm{O}$ : C $53.57 \%, \mathrm{H} 4.38 \%$. Found: C $53.71 \%$, H 4.04\%, N $<0.05 \%$ S $<0.02 \%$.

\subsection{Single-crystal $X$-ray structure analysis}

The X-ray intensity data were measured on a Bruker D8 Venture diffractometer equipped with multilayer monochromators, Mo K/ $\alpha$ INCOATEC micro focus sealed tubes and Oxford system. The structures were solved by direct methods and refined by full-matrix least-squares techniques. Non-hydrogen atoms were refined with anisotropic displacement parameters. Hydrogen atoms were inserted at calculated positions 
and refined with riding model. The following software was used: Bruker SAINT software package [46] using a narrow-frame algorithm for frame integration, SADABS [47] for absorption correction, OLEX2 [48] for structure solution, refinement, molecular diagrams and graphical user-interface, SHELXLE [49] for refinement and graphical user-interface SHELXS-2015 [50] for structure solution, SHELXL-2015 [51] for refinement, Platon [52] for symmetry check and $\pi-\pi$ interactions. Experimental data for complexes [Os $\left(\eta^{6}-p\right.$-cymene $\left.)(p h t h) C l\right]$, [Ru( $\eta^{6}-p$-cymene)(phth)Cl], $\quad\left[\mathrm{Ru}\left(\eta^{6}-p\right.\right.$-cymene)(phth)Br], $\left[\mathrm{Ru}\left(\eta^{6}-p\right.\right.$-cymene)(phth)I] and $\left[\mathrm{Rh}\left(\eta^{5}-\mathrm{C}_{5} \mathrm{Me}_{5}\right)(\mathrm{phth}) \mathrm{Cl}\right]$ (available online: http://www.ccdc.cam.ac.uk/conts/retrieving.html, codes: 1961117-1961121) can be found in Table S1. Crystal data and structure refinement details for complexes are given in Tables S1-S6.

\subsection{Cell lines, culture conditions and cytotoxicity tests in cancer cell lines}

\subsubsection{Cell lines and culture conditions}

CH1/PA-1 cells (identified via STR profiling as PA-1 ovarian teratocarcinoma cells by Multiplexion, Heidelberg, Germany) were a gift from Lloyd R. Kelland, CRC Center for Cancer Therapeutics, Institute of Cancer Research, Sutton, UK. SW480 (human adenocarcinoma of the colon), and A549 (human non-small cell lung cancer) cells were provided by Brigitte Marian (Institute of Cancer Research, Department of Medicine I, Medical University of Vienna, Austria). All cell culture reagents were obtained from Sigma-Aldrich and plasticware from Starlab (Germany). Cells were grown in $75 \mathrm{~cm}^{2}$ culture flasks as adherent monolayer cultures in minimum essential medium (MEM) supplemented with $10 \%$ heat-inactivated fetal calf serum $\left(\mathrm{Gibco}^{\mathrm{TM}}\right.$, Thermo Fisher), $1 \mathrm{mM}$ sodium pyruvate, $4 \mathrm{mM}$ L-glutamine, and $1 \%$ non-essential amino acids (from $100 \times$ ready-to-use stock). Cultures were maintained at $37{ }^{\circ} \mathrm{C}$ in humidified atmosphere composed of $95 \%$ air and $5 \%$ $\mathrm{CO}_{2}$.

\subsubsection{MTT assay}

Cytotoxic effects were determined by means of a colorimetric microculture assay (MTT assay). For this purpose, cells were harvested from culture flasks by trypsinization and seeded in $100 \mu \mathrm{L} /$ well aliquots into 96-well microculture plates. Cell densities of $1.0 \times 10^{3}$ cells/well (CH1/ PA-1), $2.0 \times 10^{3}$ cells/well (SW480), and $3.0 \times 10^{3}$ cells/well (A549) were chosen in order to ensure exponential growth of untreated controls throughout the experiment. Cells were allowed to settle and resume exponential growth in drug-free complete culture medium for $24 \mathrm{~h}$. The compounds were then dissolved in DMF (compounds 4,6 ) or DMSO (all other compounds) first, diluted in complete culture medium and added to the plates where the final DMF/DMSO content did not exceed $0.5 \%$. After $96 \mathrm{~h}$ of exposure, all media were replaced with $100 \mu \mathrm{L} /$ well of a 1:7 MTT/RPMI 1640 solution (six parts of RPMI 1640 medium supplemented with $10 \%$ heat-inactivated fetal bovine serum and $4 \mathrm{mM} \mathrm{L-glu-}$ tamine; one part of $5 \mathrm{mg} / \mathrm{mL}$ MTT reagent in phosphate-buffered saline (PBS)). After incubation for $4 \mathrm{~h}$, the supernatants were removed and the formazan crystals formed by viable cells were dissolved in $150 \mu \mathrm{L}$ DMSO per well. Optical densities at $550 \mathrm{~nm}$ were measured with a microplate reader (BioTek ELx808) using a reference wavelength of $690 \mathrm{~nm}$ to correct for unspecific absorption. The quantity of viable cells was expressed as percentage of untreated controls, and $50 \%$ inhibitory concentrations $\left(\mathrm{IC}_{50}\right.$ ) were calculated from concentration-effect curves by interpolation. Evaluation is based on means from at least three independent experiments, each comprising three replicates per concentration level.

\section{Conclusions}

Phthiocol and lawsone are 2-hydroxy-[1,4]-naphthoquinones with pronounced bioactivity and redox chemistry; therefore the complexa- tion with metal ions, such as Ru(II)-, Os(II)- and Rh(III)-arene is a promising approach for the development of novel organometallic compounds with anticancer properties. Within this work, six naphthoquinone-based complexes with different metal centers, arenes, chelating ligands and leaving groups were synthesized and characterized. The analysis of the single-crystal X-ray data of the phthiocol-based organometallic complexes showed that the exchange of the metal center with a higher charged metal ion affects the bond lengths of the coordination bonds considerably. The cytotoxic properties of the compounds in three human cancer cell lines and their solution chemistry were investigated. The performed structural variations did not lead to an increase in cytotoxicity in the used cancer cells compared to the most cytotoxic compound $\mathbf{1 .}$

Solution equilibrium chemistry was investigated systematically for $\mathrm{Ru}\left(\eta^{6}-p\right.$-cymene), $\mathrm{Ru}\left(\eta^{6}\right.$-toluene) and $\mathrm{Rh}\left(\eta^{5}-\mathrm{C}_{5} \mathrm{Me}_{5}\right)$ complexes of both ligands with natural origin, and stability constants were determined. The observed trend of the stability constants is the following: $\operatorname{Ru}\left(\eta^{6}-p\right.$-cymene $)>\operatorname{Ru}\left(\eta^{6}\right.$-toluene $)>\operatorname{Rh}\left(\eta^{5}-C_{5} \mathrm{Me}_{5}\right)$, which is the same as it was found earlier for other $(O, O)$ bidentate ligand complexes. Despite this trend the $\left[\mathrm{Rh}\left(\eta^{5}-\mathrm{C}_{5} \mathrm{Me}_{5}\right)(\mathrm{phth}) \mathrm{Cl}\right]$ complex has the highest solution stability at physiological $\mathrm{pH}$ among the studied complexes. Notably, the tested complexes have generally lower stability compared with those of other ligands bearing $(O, O)$ donor set.

\section{Declaration of competing interest}

The authors declare that they have no known competing financial interests or personal relationships that could have appeared to influence the work reported in this paper.

\section{Acknowledgement}

This work was supported by National Research, Development and Innovation Office-NKFIA through projects GINOP-2.3.2-15-2016-00038, FK 124240 and FIKP program TUDFO/47138-1/2019-ITM.

\section{Appendix A. Supplementary data}

Supplementary data to this article can be found online at https://doi. org/10.1016/j.jorganchem.2019.121070.

\section{References}

[1] I. Ott, R. Gust, Arch. Pharm. 340 (2007) 117-126, doi:10.1002/ ardp. 200600151.

[2] N. Muhammad, Z. Guo, Curr. Opin. Chem. Biol. 19 (2014) 144-153, doi:10.1016/j.cbpa.2014.02.003.

[3] R. Trondl, P. Heffeter, C.R. Kowol, M.A. Jakupec, W. Berger, B.K. Keppler, Chem. Sci. 5 (2014) 2925-2932, doi:10.1039/C3SC53243G.

[4] E. Alessio, Eur. J. Inorg. Chem. 2017 (2017) 1549-1560, doi:10.1002/ ejic. 201600986.

[5] J. Coverdale, T. Laroiya-McCarron, I. Romero-Canelón, Inorganics 7 (2019) 31-45, doi:10.3390/inorganics7030031.

[6] Y. Kumagai, Y. Shinkai, T. Miura, A.K. Cho, Annu. Rev. Pharmacol. Toxicol. 52 (2012) 221-247, doi:10.1146/annurev-pharmtox-010611-134517.

[7] C.O. Salas, M. Faúndez, A. Morello, J.D. Maya, R.A. Tapia, Curr. Med. Chem. 18 (2011) 144-161, doi:10.2174/092986711793979779.

[8] H. Babich, A. Stern, J. Appl. Toxicol. 13 (1993) 353-358, doi:10.1002/ jat.2550130510.

[9] Q. Zhang, J. Dong, J. Cui, G. Huang, Q. Meng, S. Li, Chem. Pharm. Bull. 66 (2018) 612-619, doi:10.1248/cpb.c18-00013.

[10] K.W. Wellington, RSC Adv. 5 (2015) 20309-20338, doi:10.1039/C4RA13547D.

[11] I.T. Crosby, D.G. Bourke, E.D. Jones, P.J. de Bruyn, D. Rhodes, N. Vandegraaff, S. Cox, J.A.V. Coates, A.D. Robertson, Bioorg. Med. Chem. 18 (2010) 6442-6450, doi:10.1016/j.bmc.2010.06.105.

[12] O. Pawar, A. Patekar, A. Khan, L. Kathawate, S. Haram, G. Markad, V. Puranik, S. Salunke-Gawali, J. Mol. Struct. 1059 (2014) 68-74, doi:10.1016/ j.molstruc.2013.11.029.

[13] S.H. Wang, C.Y. Lo, Z.H. Gwo, H.J. Lin, L.G. Chen, C.D. Kuo, J.Y. Wu, Molecules 20 (2015) 11994-12015, doi:10.3390/molecules200711994. 
[14] C.M. Hackl, B. Schoenhacker-Alte, M.H.M. Klose, H. Henke, M.S. Legina, M.A. Jakupec, W. Berger, B.K. Keppler, O. Brüggermann, I. Teasdale, P. Heffeter, W. Kandioller, Dalton Trans. 46 (2017) 12114-12124, doi:10.1039/C7DT01767G.

[15] M. Kubanik, W. Kandioller, K. Kim, R.F. Anderson, E. Klapproth, M.A. Jakupec, A. Roller, T. Söhnel, B.K. Keppler, C.G. Hartinger, Dalton Trans. 45 (2016) 13091-13103, doi:10.1039/c6dt01110a.

[16] W. Kandioller, E. Balsano, S.M. Meier, U. Jungwirth, S. Göschl, A. Roller, M.A. Jakupec, W. Berger, B.K. Keppler, C.G. Hartinger, Chem. Commun. 49 (2013) 3348-3350, doi:10.1039/c3cc40432c.

[17] L. Tabrizi, H. Chiniforoshan, J. Organomet. Chem. 822 (2016) 211-220, doi:10.1016/j.jorganchem.2016.09.003.

[18] L. Tabrizi, H. Chiniforoshan, Dalton Trans. 46 (2017) 2339-2349, doi:10.1039/ C6DT04339A.

[19] S.J. Dougan, A. Habtemariam, S.E. McHale, S. Parsons, P.J. Sadler, Proc. Natl. Acad. Sci. U.S.A. 105 (2008) 11628-11633, doi:10.1073/pnas.0800076105.

[20] M.A. Jakupec, M. Galanski, V.B. Arion, C.G. Hartinger, B.K. Keppler, Dalton Trans. (2008) 183-194, doi:10.1039/b712656p.

[21] L. Kathawate, S.P. Gejji, S.D. Yeole, P.L. Verma, V.G. Puranik, S. Salunke-Gawali, J. Mol. Struct. 1088 (2015) 56-63, doi:10.1016/ j.molstruc.2015.01.053.

[22] R. Zhu, L. Xing, X. Wang, C. Cheng, B. Liu, Y. Hu, Synlett 2007 (2007) 2267-2271, doi:10.1055/s-2007-985584.

[23] H.P. Varbanov, S. Göschl, P. Heffeter, S. Theiner, A. Roller, F. Jensen, M.A. Jakupec, W. Berger, M. Galanski, B.K. Keppler, J. Med. Chem. 57 (2014) 6751-6764, doi:10.1021/jm500791c.

[24] M.V. Babak, S.M. Meier, K.V.M. Huber, J. Reynisson, A.A. Legin, M.A. Jakupec, A. Roller, A. Stukalov, M. Gridling, K.L. Bennett, J. Colinge, W. Berger, P.J. Dyson, G. Superti-Furga, B.K. Keppler, C.G. Hartinger, Chem. Sci. 6 (2015) 2449-2456, doi:10.1039/C4SC03905J.

[25] S. Grgurić-Šipka, I. Ivanović, G. Rakić, N. Todorović, N. Gligorijević, S. Radulović, V.B. Arion, B.K. Keppler, Eur. J. Med. Chem. 45 (2010) 1051-1058, doi:10.1016/j.ejmech.2009.11.055.

[26] I. Bratsos, D. Urankar, E. Zangrando, P. Genova Kalou, J. Košmrlj, E. Alessio, I. Turel, Dalton Trans. 40 (2011) 5188-5199, doi:10.1039/C0DT01807D.

[27] L. Bíró, A.J. Godó, Z. Bihari, E. Garribba, P. Buglyó, Eur. J. Inorg. Chem. (2013) 3090-3100, doi:10.1002/ejic.201201527.

[28] O. Dömötör, S. Aicher, M. Schmidlehner, M.S. Novak, A. Roller, M.A. Jakupec, W. Kandioller, C.G. Hartinger, B.K. Keppler, É. Enyedy, J. Inorg. Biochem. 34 (2014) 57-65, doi:10.1016/j.jinorgbio.2014.01.020.

[29] E.B. Ball, J. Biol. Chem. 106 (1934) 515-524.

[30] A. Beauchamp, R.L. Benoit, Can. J. Chem. 44 (1966) 1607-1613, doi:10.1139/ v66-244.

[31] L. Bíró, E. Farkas, P. Buglyó, Dalton Trans. 41 (2012) 285-291, doi:10.1039/ c1dt11405k.

[32] É. Enyedy, O. Dömötör, C.M. Hackl, A. Roller, M.S. Novak, M.A. Jakupec, B.K Keppler, W. Kandioller, J. Coord. Chem. 68 (2015) 1583-1601, doi:10.1080/ 00958972.2015 .1023195$.

[33] J.P. Mészáros, J.M. Poljarevic, G.T. Gál, N.V. May, G. Spengler, É. Enyedy, J. Inorg. Biochem. 195 (2019) 91-100, doi:10.1016/j.jinorgbio.2019.02.015.

[34] L. Bíró, E. Farkas, P. Buglyó, Dalton Trans. 39 (2010) 10272-10278, doi:10.1039/c0dt00469c.

[35] M. Aguilar-Martínez, N.A. Marcías-Ruvalcaba, J.A. Bautista-Martínez, M. Gómez, F.J. González, I. González, Curr. Org. Chem. 8 (2004) 1721-1738, doi:10.2174/1385272043369548.

[36] K.N. Raymond, C.J. Carrano, Acc. Chem. Res. 12 (1979) 183-190, doi:10.1021/ ar50137a004.

[37] P. Gans, A. Sabatini, A. Vacca, Talanta 43 (1996) 1739-1753, doi:10.1016/ 0039-9140(96)01958-3.

[38] H.M. Irving, M.G. Miles, L.D. Petit, Anal. Chim. Acta 38 (1967) 475-488, doi:10.1016/S0003-2670(01)80616-4.

[39] SCQuery, The IUPAC stability constants database, academic software (version 5.5), R. Soc. Chem (1993-2005).

[40] L. Zékány, I. Nagypál, in: D.L. Leggett (Ed.), Computational Methods for the Determination of Stability Constants, Plenum Press, New York, 1985, pp. 291-353.

[41] L. Ma, R. Ma, Z. Wang, S.M. Yiu, G. Zhu, Chem. Commun. 52 (2016) 10735-10738, doi:10.1039/C6CC04354B.

[42] L.E. Heim, S. Vallazza, D. van der Waals, M.H.G. Prechtl, Green Chem. 18 (2016) 1469-1474, doi:10.1039/C5GC01798J.

[43] M.G. Mendoza-Ferri, C.G. Hartinger, A.A. Nazarov, R.E. Eichinger, M.A. Jakupec, K. Severin, B.K. Keppler, Organometallics 28 (2009) 6260-6265, doi:10.1021/om900715j.

[44] J.W. Kang, K. Moseley, P.M. Maitlis, J. Am. Chem. Soc. 91 (1969) 5970-5977, doi:10.1021/ja01050a008.

[45] W.A. Kiel, R.G. Ball, W.A.G. Graham, J. Organomet. Chem. 383 (1990) 481-496, doi:10.1016/0022-328X(90)85149-S.

[46] B. AXS, Bruker SAINT v8.38A/B \& v7.56/7.68A, 2005-2019.

[47] G.M. Sheldrick, SADABS, University of Göttingen, Germany, 1996.

[48] O.V. Dolomanov, L.J. Bourhis, R.J. Gildea, J.A.K. Howard, H. Puschmann, J. Appl. Crystallogr. 42 (2009) 339-341, doi:10.1107/S0021889808042726.

[49] C.B. Hubschle, G.M. Sheldrick, B. Dittrich, J. Appl. Crystallogr. 44 (2011) 1281-1284, doi:10.1107/S0021889811043202.

[50] G.M. Sheldrick, SHELXS v 2016/4, University of Göttingen, Germany, 2015.

[51] G.M. Sheldrick, SHELXL v 2016/4, University of Göttingen, Germany, 2015.

[52] A.L. Spek, Acta Crystallogr. D65 (2009) 148-155, doi:10.1107/ S0021889802022112. 